THE MOTION PiCTURE INDUSTRY:

Critical Issues In Practice, CuRRENT Research, AND NEW RESEARCH Directions

\author{
Jehoshua Eliashberg \\ Sebastian S. Kresge \\ Professor of Marketing \& \\ Professor of Operations and \\ Information Management \\ The Wharton School \\ University of Pennsylvania \\ Philadelphia, U.S.A. \\ +16106491926 \\ eliashberg@wharton.upenn.edu \\ Anita Elberse \\ Assistant Professor \\ Harvard Business School \\ Harvard University \\ Boston, U.S.A. \\ +16174956080 \\ aelberse@hbs.edu
}

\section{Mark A.A.M. Leenders}

\author{
Assistant Professor \\ The Amsterdam School of \\ Communications Research \\ University of Amsterdam \\ Amsterdam, the Netherlands \\ +31205256689 \\ m.a.a.m.leenders@uva.nl
}

Acknowledgements: The authors thank Peter Davis, Liran Einav, Ron Goettler, Chuck Moul, Barak Orbach, Martin Peitz, Olav Sorenson, the reviewers, the Associate Editor, and the Editor for helpful comments and suggestions. Jehoshua Eliashberg acknowledges the support provided by the Fishman-Davidson Center for Service and Operations Management at the Wharton School; Anita Elberse acknowledges the support provided by the Division of Research at Harvard Business School; Mark Leenders acknowledges the support of the Erasmus Research Institute of Management.

First Draft: May 29, 2004

Revised: February 23, 2005

Revised: August 29, 2005 
THE MOTION PICTURE INDUSTRY:

\title{
Critical IsSUes In Practice, CuRRENT RESEARCH, AND NEW RESEARCH DiRECTIONS
}

\begin{abstract}
The motion picture industry has provided a fruitful research domain for scholars in marketing and other disciplines. The industry has a high economic importance and is appealing to researchers because it offers both rich data that cover the entire product lifecycle for a large number of new products and because it provides many unsolved 'puzzles'. Although the amount of scholarly research in this area is rapidly growing, its impact on practice has not been as significant as in other industries (e.g., consumer packaged goods). In this article, we discuss critical practical issues for the motion picture industry, review existing knowledge on those issues, and outline promising research directions. Our review is organized around the three key stages in the value chain for theatrical motion pictures: production, distribution, and exhibition. Focusing on what we believe are critical managerial issues, we propose various conjectures, framed either as research challenges or specific research hypotheses, related to each stage in the value chain and often involved understanding consumer movie-going behavior.
\end{abstract}

Keywords: Motion Picture Industry, Entertainment Industry, Review, Research and Models 


\section{INTRODUCTION}

Over the last two decades, the amount of academic research on issues related to the motion picture industry has risen sharply. There are several possible reasons. First, the industry has a high economic importance in the global economy. The motion picture industry employs over half a million people in the U.S. (U.S. Department of Labor 2004). Spending only on theatrical tickets was around \$9 billion in the U.S. (and Canada) and close to \$11 billion outside the U.S. in 2004; revenues from ancillary markets (particularly home video, but also merchandising) are several times higher (Standard \& Poor's 2004). Motion pictures are a key driver of the market for entertainment products—currently the number one export market for the U.S. Second, the industry has high cultural significance and it attracts quite a bit of attention-motion pictures have a disproportional impact on American (and perhaps world) culture. Unlike any other product, statistics about weekend box office feature in news reports virtually every week. Third, the availability of rich data makes the industry particularly appealing from a research perspective. For example, many new, unique products are released in a relatively short time period. The 'cradle-to-grave' scope, with data covering the entire product life cycle, provides ideal conditions for marketing researchers. Fourth, industry practitioners rely heavily on tradition, conventional wisdom, and simple rules of thumb, which often have not been- but should be-closely examined. Intriguing puzzles still exist, such as the extent to which traditional contracts among channel partners or uniform ticket pricing policies are optimal. Fifth, insights from the motion picture industry may help to better understand industries that share certain characteristics as well as to examine the interface between technology and experience goods in the digital age (Schmitt 1999; Wolf 1999).

In this article, we set out to review the rapidly growing body of research on the motion picture industry for two main reasons. First and foremost, we believe that a reassessment of research directions is needed, particularly when many critical issues for practice remain unaddressed. Our goal here is to share insights into the motion picture industry in such a way that they will stimulate research that is relevant to management. Second, we are convinced that a greater focus on industry-specific research can benefit the marketing discipline; we hope that our review will exemplify an approach to the development of a research agenda, stimulating similar efforts for other industries. 
We focus on the theatrical motion picture industry and divide the manuscript into three sections production, distribution, and exhibition -corresponding to the three key stages in the value chain for theatrical motion pictures that precede their 'consumption' by movie-going audiences (see Figure 1).

Figure 1: The Value Chain for Motion Pictures

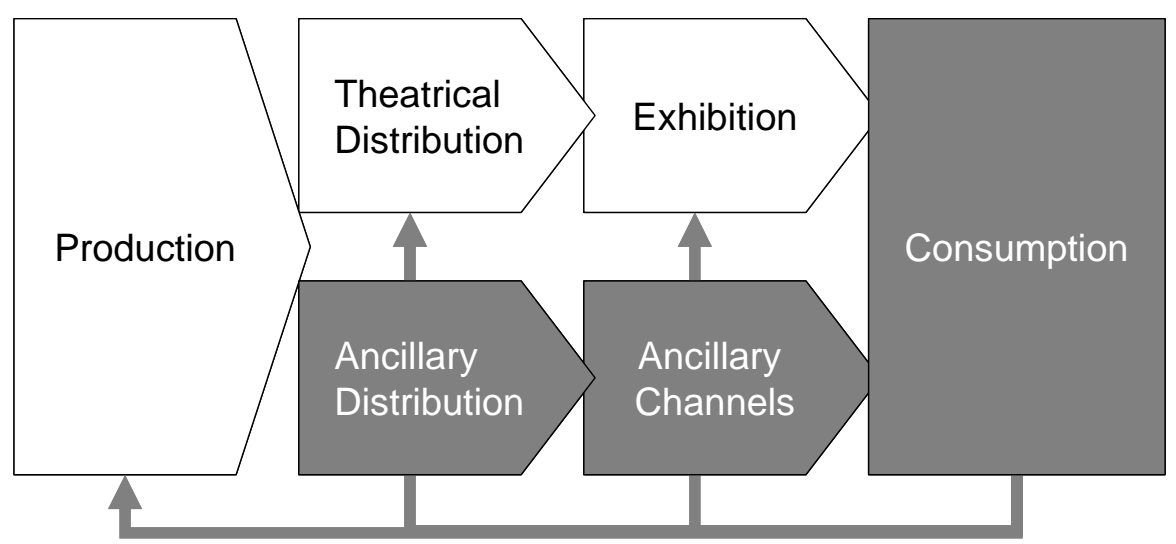

Different types of entities and individuals participate in each stage of the value chain. The competitive landscape includes vertically integrated major studios, independent production companies, independent distributors, major national exhibition chains, and smaller regional exhibitors and art houses. Studios are often simultaneously engaged in four distinct functions: financing, producing, distributing, and advertising (Squire 2004, Vogel, 2001). Here, we consider the first two functions together under the heading 'Production'. It can be defined as the activities needed to produce one copy (or, in industry terms, one 'print') of the movie. The latter two functions are discussed under the heading 'Distribution'. In essence, these functions encompass all of the distributor's interactions with its two main groups of customers - exhibitors and audiences. 'Exhibition' refers to activities performed by theater chains and individual theater sites.

We recognize that the motion picture industry encompasses a number of subsequent revenue windows, including local and global theatrical, home video, pay television, network television, syndication, video games and merchandising. Although a comprehensive review of non-theatrical windows is beyond the scope of our study, we venture into these areas to the extent that they are relevant to the behavior of players involved in the theatrical arena. 
The three sections are structured in a similar way. We begin each with a description of the general process and current status of research. Next, we describe key practical issues which, in our opinion, are worthy of research. We do not intend our descriptions of practical issues to be exhaustive; instead, we set out to highlight what we view as critical issues, for each stage of the value chain, based on our knowledge of the industry, interactions with industry executives and observers, and review of trade publications. We propose various conjectures - inferences based on inconclusive or incomplete evidence - and research challenges. We acknowledge that the conjectures are often speculative. Our aim is to examine the extent to which critical issues have already been studied - and if so, what key findings emerge - and to what extent they have not. Our review shows that the range of methodologies employed in existing research is already quite broad, and includes regression-based econometric techniques, discrete-choice models, and operations research methods. However, our focus is not on the methodologies employed.

Closely related to our theme, but not reviewed in this paper because of the availability of other reviews (e.g., Litman and Ahn 1998), is the literature that deals with consumers and their moviegoing behavior ${ }^{1}$. An understanding of audience behavior is fundamental to shedding more light on the challenges faced by producers, distributors, and exhibitors. Attempts to understand what drives movie consumption date back at least as far as 1914, when DeMaday (1929) asked Swiss school children 'why do you like going to the cinema?' (Palmgreen, Cook, Harvill, \& Helm, 1988). Jowett (1985) provides an informative review of movie audience research in the first half of the 20th century. He observed that "no major American industry ever operated with so little research of its market as did the motion picture industry during the period of its greatest

\footnotetext{
${ }^{1}$ The literature in this area has been divided into two research traditions: the 'psychological approach' and the 'economic approach'. The 'psychological approach' focuses on individual decisions: to choose movies from among the vast array of entertainment options and, more critically, to choose a particular movie (e.g. Litman \& Ahn, 1998). Researchers adopting this approach aim to relate such variables as opinions, needs, values, attitudes, moods and personality traits to consumers' decision-making processes. Such studies generally use data collected by surveying individual consumers. Examples are Austin (1986; 1989), Becker et al (1985), Cuadrado and Frasquet (1999), D'Astous and Touil (1999), De Silva (1998), Eliashberg and Sawhney (1994), Moller and Karppinen (1983), Palmgreen et al (1988), and Palmgreen and Lawrence (1991). The economic approach seeks to explore the variables that influence the financial performance of motion pictures. These studies typically use aggregate data on movie-going behavior collected by industry trade sources. Examples include Litman (1983), Litman and Kohl (1989), Litman and Ahn (1998), De Vany \& Walls (2000), Dodds and Holbrook (1988), Elberse \& Eliashberg (2003), Eliashberg and Shugan (1997), Hennig-Thurau, Walsh and Wruck (2001), Jedidi, Krider and Weinberg (1998), Moul (2004), Prag and Casavant (1994), Ravid (1999), Simonoff and Sparrow (2000), Smith and Smith (1986), Sochay (1994), Wallace et al (1993), and Zufryden (1996; 2000). Some studies, effectively bridging both approaches, model aggregate patterns of motion picture diffusion based on assumptions about underlying adoption processes on an individual level (e.g. De Vany \& Walls 1996; Neelamegham and Chintagunta 1999, Sawhney \& Eliashberg, 1996).
} 
influence, from its early years until the mid-1950s". It was not until the 1940s that the industry began to move beyond anecdotal studies to more systematic research methods, most often regularly administered surveys. In that period, academic researchers such as Lazersfeld (1947) laid the groundwork for further research on movie audiences, in areas such as psychology, sociology, communications, and film studies (see Blowers 1991). More recently, conceivably partly in response to Hollywood's increased focus on 'the bottom line', interest in the motion picture industry has spread to other fields - particularly industrial organization, economics, strategy, and marketing.

\section{PRODUCTION}

The development of a motion picture is a long succession of creative decisions with far-reaching economic implications for the different players involved. Each movie's development process is unique, but some general observations can be made. The process commonly begins with a story concept based on a literary property, a new idea or a true event (Vogel, 2001, Squire 2004), which can vary from a general idea (a 'pitch') to a completed screenplay (a 'spec'). In some cases, a studio or producer will ask a writer to develop a new (or adapt an existing) screenplay. Usually, however, with help from a literary agent, a writer submits a first draft of a screenplay for review to a number of independent and/or studio affiliated producers. If a producer is interested - many screenplays never pass this hurdle - both parties usually sign an option agreement, which gives the producer the right to purchase the complete screenplay, and the writer an advance payment (of which the literary agent takes a percentage).

At this point, substantial financing is required to take the project into production. Financing is less problematic if the producer is affiliated with a studio (an example is the deal that Ron Howard and Brian Grazer's production company Imagine Entertainment has made with Universal Studios). By signing a studio contract a producer usually gives up a wide range of rights relating to sequels, spin-offs, merchandising, and other opportunities, but at the same time increases his chances of securing bank loans or tapping into the studio's own capital, and of securing favorable distribution and exhibition deals for completed movies. Such contracts are beneficial from the studio's perspective because they guarantee the inflow of products from firms with solid track records. Financing is significantly more problematic if the producer does not have a pact or a deal with a studio, which is the case for many projects. In that case, the producer will have to obtain 
initial financing from other sources, which is particularly difficult when no distribution deals are guaranteed (Vogel 2001).

While they pursue different fund-raising options, producers also have to develop the film along other lines: they recruit the director, cast, and crew, scout possible shooting locations, and design sets and costumes, among other things. Talent agents (such as $C A A$ and $I C M$ ) play a key role in these activities. At this stage, producers also determine an estimated production budget, based on such factors as the script, likely post-production expenses (e.g. for special effects), star salaries, and financing possibilities. After these activities, which are all part of the 'pre-production' phase, the project enters the actual 'production' phase in which the film is shot. This usually lasts a few months. Next, the project enters 'post-production', which consists of activities such as editing, dubbing, creating special effects, and adding music. Before it can be released in a particularly country, the movie also needs to be rated (e.g., by the MPAA in the U.S.).

The above description applies mostly to the movie development process in the U.S. Movies originating in 'Hollywood' dominate box-office rankings across the globe. However, of the more than 4,000 movies produced worldwide each year, only about 700 are produced in the U.S. (MPAA, 2003; also see Scott 2005). India is the most productive country. Its motion picture industry, sometimes referred to as 'Bollywood', produced more than 1,000 films in 2001, which together generated over 45 billion rupees (at the time close to $\$ 1$ billion) in revenues (U.K. Film Council, 2002). Overseas markets such as the U.K. have become increasingly lucrative for Indian films, sometimes generating nearly a third of total revenues, and allowing for higher production budgets. With the notable exception of India, Hollywood products dominate major markets around the world. Even in countries with highly acclaimed local productions, such as France and Italy, non-U.S. movies often account for only a small fraction of box-office grosses (EAO 2003).

Financing the development of a movie is an extremely risky decision rooted in artistic and business considerations. However, we believe that:

\section{The Success Rate of the Traditional 'Green-Lighting' Process can be improved}

An important puzzle in the motion picture industry is why movies that flop miserably at the box office ever get made. Caves (2001) provides arguments for why such 'ten-ton turkeys' advance through the development process. He suggests that when costs are sunk progressively and 
information on a project's quality is revealed gradually, rational decision makers can carry projects to completion that realize enormous ex post losses. The movie The Adventures of Pluto Nash, which cost over $\$ 100$ million to produce but earned less than $\$ 5$ million in U.S. theaters, is an example of such a type II error. Type I errors, which involve rejecting a potentially successful project, are also a common practice in the industry: a recent example is The Passion of the Christ, the highest-grossing independent movie to date, which was reportedly turned down by several major studios (Quelch et al 2004).

It is because of the 'triggering' effect outlined by Caves (2001) that mistakes in the green-lighting process - the initial decision to approve or decline a project—are so costly. While maximizing the green-lighting success rate (i.e., minimizing the two types of errors) is extremely challenging, it is staggering to discover how little 'science' usually goes into the process. A senior executive at a major studio described the process as follows: "We bring together all studio department heads. Beforehand, our financial department prepares an overview of key estimates to get a sense of the financial viability. It really revolves around the production costs. That is our most reliable estimate, and that thus forms the basis for our launch decision...The idea is to work towards the bottom line. We ask ourselves whether we can recover our production costs, and whether there is room to spend on marketing. In the end, though, it comes down to the fact that someone has to sign off on the deal. Someone in the meeting has to put his or her reputation on the line and say 'yes' - regardless of whether the numbers add up" (Elberse, 2002).

The green-lighting decision can never be completely foolproof, and the decision should not always be guided by economic analysis. However, given the advances that marketing scholars have made in the past decades in the general area of new product development (e.g. Urban and Hauser 1980; Wind and Mahajan 1997, Crawford and Di Benedetto 2003), and in particular with expert and knowledge-based computer systems(e.g., Burke et al 1990, Rangaswamy et al 1989) already employed by practitioners in creative industries such as the advertising industry, quantitative and qualitative (e.g., linguistics analysis) research methods may be able to facilitate decision-making and improve the success rate. Even a marginal decrease in failure rate of the green-lighting process could confer tremendous financial and reputation benefits for studios and other players involved.

Marketing researchers have already made significant progress in developing early-stage boxoffice forecasting models and decision support tools, including models predicting success and 
aiding decision-making after the movie has been completed but before it is released in theaters (e.g. Neelamegham and Chintagunta 1999; Eliashberg, Jonker, Sawhney and Wierenga 2000; Shugan and Swait 2000). Also applicable to earlier stages of the development process, work by De Vany and Walls (1999) and Collins, Hand, and Snell (2002) provides insights into the probability that a film's revenue will exceed a given threshold value. A team evaluation approach as proposed by Shugan (2000a; 2000b), basing predictions on information about the past performance of production team members, is promising as well.

Another interesting new method involves stock markets simulations. Some marketing researchers have shown that such 'predictive' markets, used to identify 'winning concepts' in the eyes of consumers for other goods (see Dahan and Hauser, 2002), can generate, at an early stage, valuable insights into the likely success of motion pictures (Gruca 2000; Elberse \& Eliashberg 2003; Spann and Skiera 2003; Elberse and Anand 2005). The Hollywood Stock Exchange (HSX, www.hsx.com) has been the most popular application in the motion picture industry. For example, Spann and Skiera (2003) show that data obtained using HSX, when incorporated into a conventional regression model, lead to a significant improvement in opening weekend forecasts.

One possible reason for why virtual stock markets are helpful in assessing demand relates to a key observation about movie consumption - moviegoers appear heavily influenced by others' opinions and choices. 'Others' could refer to friends and acquaintances, critics and other opinion leaders, as well as the market as a whole. The most direct influence is likely to come from people that accompany consumers to the theater. It is well established that movie attendance has a strong social component (e.g., Austin 1986). Weinberg (2005) speculates about the effect of the collective nature of the decision-making process on consumption. He suggests that there might be an elimination rule, whereby a movie is eliminated from the consideration set if any of the group members has already seen it, or if any of the group members vetoes against it. Prior information, opinion leadership, and group composition could impact this process. In essence, the problem involves understanding how to 'translate' individual utility to joint utility.

The large body of econometric research on the many factors that drive the success of motion pictures may provide useful guidance as well (see Litman (1983) for pioneering work in this area, and Elberse (2002) and Elberse and Eliashberg (2003) for recent overviews). Many of these models consider factors which are under the direct control of a studio and/or producer (e.g. the director, cast, genre, and production budget) and which often form the basis for the green-lighting 
decision. However, it is important to consider potential endogenous relationships in empirical examinations (see Shugan 2004). For example, a high budget means that the movie can employ high-profile stars, but high-profile stars generally also attract financing, which in turn enables a higher production budget. Decisions on which stars to employ and what budgets to set, as well as financial estimates based on both considerations, should take this endogeneity into account. Another factor that is worthwhile to consider at an early stage in the development process is the expected rating - both in the U.S. and overseas. Leenders and Eliashberg (2004) found that parental guidance ratings for a particular movie often differ significantly across countries. In addition, they found that the relationship between movies' ratings and their box office success differs across countries.

The following questions may capture some particularly worthwhile research avenues:

- How should agents and other intermediates bring screenplays to the market?

- What screenplays are/should be picked up by studios - and why?

- How the green-lighting decision-making process is currently structured and how can it be improved? The focus here could be on designing appropriate stage-gate procedures with specific metrics and milestones that allow for shelving or aborting the project, committee composition, and voting rules, among other things.

- What determines the manner in which projects progress (or fail to progress) in the development funnel? How do studios make the trade-off between artistic and business objectives? How can this process be optimized?

- Can accurate forecasting models be developed based on very early information and indicators, such as a movie's script, the cast, and the expected rating?

We anticipate improvements in the accuracy of risk assessments by studios and independent production firms. As far as reducing risk and creating return on investment is concerned, we conjecture that there will be a stronger reliance on content that audiences are familiar with:

\section{Studios Will Increasingly Pursue 'Hit Franchises' Based on Established Intellectual Properties in an Effort to Reduce Risks}

Producing movies is very costly and very risky. In 2003, a major studio movie required nearly \$64 million in production ('negative') costs and another \$40 million for prints and advertising costs (MPAA 2004), yet most movies never recoup those costs. Desai, Loeb and Veblen (2002) 
describe three main risks that motion pictures face: completion risk, performance risk, and financial risk. Films face completion risk due to the high level of required investment and the changing motivations and relationships between producers, talent, and financiers. They face performance risk because factors such as the uncertain appeal of stars and the fickle reactions of audiences and critics make it difficult to accurately predict revenues and profits; each movie is unique. For that very reason, equity investors face financial risk as well. Desai et al (2002) argue that, in line with an increase in production and marketing costs, the level of financial risk for equity investors has increased steadily since the 1980s. Higher dollar returns are now required in order to yield a positive net present value for investors. Many individual and institutional investors have been disappointed by the return on investment. Managing increased costs with fewer potential investors has created a serious funding problem for major studios and independents alike.

One way in which studios are coping with risk is to pursue franchises based on properties that have demonstrated their appeal in the marketplace. Studios are capitalizing on brand equity. The popularity of movie sequels best exemplifies this trend. It is by no means unique to the motion picture industry; 'tweaking' established formats is a popular strategy in other creative industries, such as television and video games (Variety 2004a; 2004b). However, the prevalence of sequels (and prequels or beginnings) in Hollywood is striking. At least a dozen sequels were shown in theaters in the summer of 2003 alone (Variety 2003d). There are a number of reasons for this preference for sequels. They appear to outperform original concepts at the box office; i.e. seem a 'safer bet'. Of the ten highest-grossing movies in 2003, four were sequels: The Matrix Reloaded, X2: X-Men United, Terminator 3, and Bad Boys 2. A fifth, Chicago, was based on a successful Broadway musical. Furthermore, sequels might be more cost-efficient to develop and market. Exhibitors and other players will display more enthusiasm for a well-established movie property, which makes a wide distribution strategy more viable. Audiences are already familiar with the concept, which makes advertising easier. It is increasingly important that the establishment of a movie franchise also seems advantageous in the home video window - sequels appear to have particularly strong DVD sales - and in ancillary windows such as video games and merchandising (Variety 2004a; 2004b).

However, the success of sequels is far from guaranteed. High-profile sequels regularly disappoint at the box office (Variety 2003d). In addition, particularly due to the exploding cost of talent, production costs are often significantly higher for sequels. Marc Schmuger, Vice Chairman at 
Universal Studios, commented in this regard: "It's a complex equation that figures in determining whether the sequel is capable of capturing the same level of excitement as the original" (Variety 2003d). Interestingly, Sood and Dreze (2004), who consider movie sequels as brand extensions and focus on the role that their titles play, find that a sequel with a numbered title (e.g., Daredevil 2) may have a less favorable evaluation than a sequel with a more descriptive title (e.g., Daredevil: Taking It to the Street).

Studios' eagerness to produce movie sequels, remakes, and movies based on properties established in other media, such as musicals, books, comics, old TV programs, and video games, is likely to continue. However, it remains to be seen whether pursuing hit franchises based on familiar properties leads to more favorable risk-return ratios.

Promising avenues for further research include:

- To what extent are sequels more profitable than movies based on original concepts?

- What kind of movie is amenable to a successful sequel and what kind is not? What type of market research is most useful in testing for a movie's sequel potential, both before and after the movie has been released?

- What type of contracts are most appropriate for movies with a high "sequel potential"? For example, how should studios contract with actors and other creative talent when a sequel is likely?

- How can studios use sequels to build and sustain valuable franchises? What is the appropriate positioning strategy for a sequel? How can studios best forecast and manage revenue streams of sequels in other windows or media?

In addition to assessing and managing risk for one particular movie or for a set of movies based on the same intellectual property, we expect that studios will (and should) pay more attention to risk management across their entire slate of movies. In this regard, we believe that:

\section{More Effective Portfolio Management Strategies Will Help Studios to Better Balance Risks and Returns}

Bringing one movie project to a successful end is difficult enough, but most studios are dividing their attention across a number of projects of various types and in various stages of development. It is difficult to obtain reliable data, but according to one comprehensive database, Buena Vista 
led the major studios with the highest number of projects - twenty-seven - in pre-production, production, or post-production in early 2004 (Showbiz Data, 2004). Even when studios are part of larger conglomerates, it is crucial for a studio to effectively manage its development 'pipeline' and carefully balance risks and returns ${ }^{2}$.

The issue extends to finding the optimal portfolio of movie types -in terms of genre, storyline, age restriction (e.g., De Vany and Walls 2002), star power, and so on - that protects a studio against changing audience tastes. In general, a portfolio-based organizational structure is believed to lead to improved performance due to the development of specialized skills. In the movie business, for instance, Focus Features, a production and distribution unit of Universal Pictures, three units, each specializing in a particular genre: "upscale action", "thriller", and "urban fare". Bob Wright, chairman and CEO of NBC Universal commented on the need for studios to have areas of expertise: "I see Universal focusing on comedies and action films. Those have been areas of real strengths” (The Wall Street Journal 2004d). Other portfolio dimensions include original versus familiar concepts (e.g., remakes and sequels), low versus high budget, in-house financing versus co-financing, track-record talent versus new creative talent, and acquisition versus inhouse development.

Studios have dealt with the uncertain success of producing movies by being acquired by large conglomerates and by increasingly turning to co-financing risk sharing arrangements. For instance, while there was only one multi-studio effort in 1993, eleven major releases in 2003 were co-ventures (Variety 2003b). In most cases, the parties involved agree to share the costs of a picture that appears to be a particularly risky proposition because of its storyline, creative talent, or production budget. Such co-financing deals usually take shape at the green-lighting stage, when estimates show that additional financial support is needed to safely go ahead with a project. Recent examples include Seabiscuit (Universal (30\%), Dreamworks (30\%) and Spyglass Entertainment (40\%) shared the \$87 million budget), Master and Commander: The Far Side of the World (Fox (50\%), Miramax (25\%) and Universal (25\%) shared the \$120 million budget) and Peter Pan (Sony (33\%), Revolution (33\%) and Universal (33\%) shared the \$102 million budget) (The Wall Street Journal, 2003). Some of these arrangements follow from ongoing production relationships between the companies involved; others are one-off deals.

\footnotetext{
${ }^{2}$ See Ding and Eliashberg (2002) for an example of effectively managing new product development pipelines in the pharmaceutical industry.
} 
Goettler and Leslie (2004), using an econometric modeling approach, found no support for the idea that studios tend to co-finance the relatively risky films, nor that portfolio diversification helps to mitigate risk. They did find, however, that co-financing helps to soften release competition, particularly for high-budget movies. That is, studios that have co-financed a movie tend to avoid head-to-head competition with other movies in their portfolio, reducing the risk of a failed opening week for the co-financed movie.

Several other factors affect studios' portfolio decisions. Producers who can bring substantial amounts of money to the table increasingly gain access to studios and drive project selection decisions (Variety 2003a). Some agencies have set up production funds to remove the financial burden from studios and generate jobs for their clients (Variety 2003b). Start-up companies offering novel ways of financing movies have entered the marketplace. One example is Civilian Pictures, which gives investors the chance to participate in small-budget films by offering filmspecific IPOs. Studios are growing more dependent on companies that are able to tap into overseas subsidies and tax incentives.

Effective portfolio management strategies may also help to secure product placements, which can help reduce costs—and thereby risks. Product placements have proliferated in many forms of entertainment, but the opportunities in motion pictures appear to be particularly lucrative, having reached a new high when Samsung paid a reported \$100 million to associate itself with The Matrix Reloaded (Variety 2003e). The phenomenon can be traced back to the late 1940s, when companies like Proctor \& Gamble first asked for their products to be worked into scripts. Placement deals come in a variety of forms, ranging from spontaneous give-away deals where no money changes hands but the product is deemed useful from a creative perspective (as was the case with Reese's Pieces in E.T. and BMW's first deal with the James Bond franchise) to fully planned placements deals that are exactly stipulated in the script against a fee. In some occasions, movie stars are required to participate in commercials for the product. Given the rise of new technologies (such as DVR) that allow consumers to skip commercials, product placements may become a more popular option for brand managers seeking to expose consumers to their products.

As product placements blur the line between entertainment and advertising (or art and commerce), research addressing two perspectives is called for. From the movie producer's perspective, the key issue is determining consumers' threshold level for product placement. From the advertiser's standpoint, the key questions are (1) what movies or movie scenes best capture 
the consumers' attention and (2) what is the value of product placements relative to traditional media vehicles such as 30 -second television commercials.

Relevant research questions include:

- Does co-financing lead to greater profitability for studios? And what is the impact of cofinancing deals on relationships with other players? For example, if two or more major studios co-finance a picture, does that give them a stronger foothold in the exhibition market for that movie, and therefore less competition? Or does softer competition mostly play out on the demand side?

- What portions of a studio's slate of movies are to be financed by the studio itself, acquired from independent production firms, or funded in other ways? What other sources of finance should studios tap?

- Studios currently appear to define their core competencies in terms of project size and genre. Along what other dimensions can they organize their portfolios?

- Are some studios 'better' at managing their pipeline? Is there a significant difference between studios' success rates? If so, what are the determinants?

- How effective is product placement in reaching a target audience, in particular relative to traditional means of advertising? What is the value to advertisers? Are product placements acceptable to moviegoers? Under what conditions?

Studios share risk not only with investors or with other studios, but also with the talent involved in the production. The conventional contract between the studio and the talent has two main parameters: fixed and performance-based compensation. We anticipate that:

\section{Conventional Contractual Arrangements with Talent Will Come under Pressure}

Thousands of people with creative roles are employed in the motion picture industry in the U.S. alone; most of them work for low salaries. However, an extremely small group is able to command much higher salaries - superstars like Tom Cruise, Tom Hanks, and Julia Roberts may receive salaries of up to $\$ 20$ million for a movie. In some instances, stars are even able to command a percentage of the gross revenues. Tom Cruise's profit-sharing arrangement for Mission: Impossible II is legendary - it reportedly yielded over $\$ 70$ million. Such salaries weigh heavily on movies' overall production budgets. 
Several researchers have studied the effect of star power. Most studies consider star power as one of the covariates in a regression model with box office performance as the dependent variable (e.g. Litman 1983; Litman \& Kohl 1989; Sochay 1994; Litman \& Ahn 1998; Wallace et al 1993). Focusing solely on the role of stars, Albert (1998) empirically shows that stars serve as the most consistent 'markers' for successful films; this, he argues, explains their power in Hollywood. But De Vany \& Walls (1999), using a probability modeling technique, conclude that audiences make movies into hits, and "no amount of 'star power' or marketing can alter that". In another study on the role of stars, Ravid (1999) finds no correlation between star participation and film revenues or profitability, which is consistent with the view that stars capture their 'economic rent'. Overall, existing evidence on the extent to which stars drive box office performance is mixed, and more research is needed to resolve this debate.

Talent compensation is likely to be a particularly pressing research issue now that some industry executives have called for a change in the reward structure for creative talent. Jeff Bewkes, a Time Warner Executive, is quoted as saying: "The only viable way to create incentives for film talent is to share the risk and the upside, and to make movie net profits mean something again" (Variety, 2002). The opinion that creative talent must share in the risk as well as the return of motion pictures is gaining popularity. However, it remains to be seen whether such a model will emerge as a viable alternative. The very box office power that makes them stars is also likely to make actors immune to such risky deals - their services are in such high demand that they can negotiate favorable terms. On the other hand, their popularity and marquee value varies with time, and it is not clear that this is accurately reflected in contracts. Talent compensation may also become a more important issue as the power of guilds and other unions of creative workers increases. The Writers Guild, for example, has recently called attention to what it sees as an unfair DVD sales reward structure for writers.

Contracting terms for actors, directors, producers, and other members of the creative community have received some attention from researchers. Chisholm (1997) has examined the choice between sharing and fixed-payment compensation schemes. She addressed the competing determinants of the decision on which contracting terms to select; these determinants include moral hazard mitigation, liquidity constraints, risk sharing, and the superstar phenomenon. Weinstein (1998) has examined competing theories of the economic function served by profitsharing contracts. He finds it is unlikely that they are the result of a standard principal-agent problem. Zuckerman and Kim (2003) addressed the optimality of contracts and contracting terms 
in their study of the types of roles actors should accept at different stages in their careers. They found that it pays for actors to accept 'typecasting' early in their careers, as it helps them to stand out in the crowd, but that there are trade-offs later.

A related issue is the desirability of long-term relationships with producers or other creative talent in the form of deals (or 'pacts', in industry jargon), which are increasingly popular among studios. The trade magazine Variety, which regularly tracks such deals, reported that over 200 producers could claim studio deals in 2003 (Variety 2003a). Sony led the other major studios with 36 deals, ranging from a deal with Adam Sandler's company Happy Madison to one with Joe Roth's Revolution Studios. Most deals give the studio a 'first look', i.e. the right to option a screenplay before other studios do. A few deals involve a longer-term relationship, as when a studio invests in a production company.

Using data that cover the financial performance of Hollywood film studios from 1936 to 1965, Miller and Shamsie (1996) study the relationship between studios' financial performance and their combination of property-based resources (exclusive long-term contracts with stars and theaters) and knowledge-based resources (production and coordinative talent and budgets). Using the same data, Miller (1999) directs his attention to the impact of uncertainty on product line variation in a study of the film genres of the major Hollywood film studios, and Miller and Shamsie (2001) examine the relationship between the level of experimentation among studio heads and their companies' financial performance.

At least, the following future research avenues emerge:

- What is "star power"? How can it be operationalized? Is past performance, on which most current metrics are based, a valid measure? To what extent is star power contingent on the nature of the movie and the characteristics of the other creative talent involved?

- To what extent do stars actually contribute to the success of movies? To what extent do they benefit from the success of movies?

- How can creative talent best pursue a career? How can actors, actresses, and other creative talent build, lose, and regain star power?

- Does the industry fluctuate in its reliance on stars in the production process? If so, why?

- What is the nature of contracts with creative talent, and how does that vary from project to project, talent to talent, or year to year? What are the profitability implications? 
Rapid advances in digital technology, often expected to be the key driver of change in the industry in the near future, have the potential to affect virtually all players involved in motion picture production, distribution, and exhibition. As far as production is concerned, we anticipate that:

\section{The Benefits of Digital Technology Will Change the Production Process but Not Lead to Fundamental Shifts in Power Structures}

Advances in digital technology have the potential to radically change the pre-production, production, and post-production stages of filmmaking (Screen Digest 2002). The potential advantages for movie producers (Belson 1996) go well beyond improving efficiency (about 85\% of the film shot at production is not used) to giving producers greater control over the entire process by making it non-linear rather than linear.

The post-production stage offers a good illustration. In its traditional, analogue form, postproduction is carried out in a sequential manner. The negative is processed and the selected shots are shipped to a post-production house for assemblage: individual sequences are physically spliced together, special effects are added, the film undergoes color timing, and the soundtrack is included. The different pieces are turned into a first cut of the original, one long reel, which in turn is used to create prints. Digital technology has the potential to make this process non-linear, and thus faster and more manageable. Scenes can be transferred from one location to the other almost instantaneously at the touch of a button, the film can be assembled without the need to process negatives, and visual and sounds effects can be prepared in advance and integrated with a great deal of flexibility (e.g. Belson 1996). Digital technology also gives producers more control over the environment in which the story is told. That is perhaps best exemplified by the use of Computer Generated Imagery (CGI), which enables intricate special effects and is now commonly used in films to create a completely virtual environment (as in Shrek), to create virtual characters that interact with a real environment (as in Jurassic Park), or to produce stand-ins for real actors in scenes requiring dangerous or impossible stunt work (as in The Matrix). The advantages extend beyond editing and recording activities. Digital technology can aid production activities performed by script writers, storyboard artists, musicians, costume designers, and location scouts, among others. It can also help in the development of marketing materials and product placements. Another advantage is that content can be customized for specific audiences. 
There are potential disadvantages, however. Some feel that the quality of digital images does not match that of analogue images captured by means of analogue $(35 \mathrm{~mm})$ cameras. While digital video recording and editing equipment is less expensive, it requires more frequent upgrading and makes producers dependent on software as well as hardware. As such, it also requires a different set of capabilities. Finally, there are piracy concerns.

Nevertheless, advances in digital technology are generally seen as a positive development for producers. George Lucas, who shot the second part of his Star Wars saga entirely on digital video cameras, is known for stating: "I can safely say that I'll never shoot another film on film" (Screen Digest 2002). Tradeoffs between development time, production cost, and product quality have already received attention from marketing researchers (e.g., Cohen, Eliashberg and Ho 1996; Bayus 1997; Bayus, Jain and Rao 1997; Hauser 2001; Bajaj, Kekre and Srinivasan 2004). It seems worthwhile to adapt the models they have proposed to the peculiar context of the motion picture industry.

Some industry observers expect that the embrace of digital technology will lead to a change in the power structure. Because lower-cost digital video cameras provide nearly, if not exactly, the same image quality as conventional 35mm cameras, and because less expensive consumer or semiprofessional cameras are increasingly used in movie production, these observers believe that digital technology will lower the barriers to market entry by enabling almost anyone with a camcorder and a personal computer to create a feature-length film. "It frees talent from the stranglehold of the Hollywood elite" (Screen Digest 2002). In addition, some think that the rising use of digital technologies will lead to a more powerful intermediary role for technology companies in the motion picture industry. While to date there is little evidence that the marketplace will broaden significantly - or that studios will want to empower an intermediary that extracts significant value - some international consolidation (where production tasks are performed in locations across the globe) seems likely. The emergence of new players that more fully exploit new production technologies (as Pixar has done in digital animation) also appears probable. A thorough analysis of strategic and policy (both regional and national) implications for existing and emerging players is warranted.

Relevant research questions may include:

- How will the motion picture value chain change in the digital age? What are the implications for the existing power structure, and the roles played by studios and 
(existing or new) intermediaries? For instance, what capabilities should studios have inhouse, and what should they outsource?

- What are the specific trade-offs (including time to market, quality, and cost) involved in moving from a mostly analogue to a fully digital movie development process?

- To what extent does digital production of a film facilitate its distribution in non-theatrical windows, such as video on demand, the Internet and mobile phones? What are the viable new channels?

- What opportunities does digital technology offer, at the production stage, for seamless integration of product placements or other forms of advertising?

\section{THEATRICAL DISTRIBUTION}

Once a project has completed production, it is ready for the next stage - distribution. This stage is commonly perceived to encompass both the physical distribution of the prints to the theaters and the marketing activities in each of the markets in which the movie is released. Studios/distributors face a wide range of marketing decisions in this stage, including when to release theatrically, on how many screens to open, and which media to use in the advertising campaign.

As far as the key players in this stage are concerned, a distinction is usually made between 'major' and 'independent' studios/distributors. The 'majors' include Paramount (Viacom), Columbia Tristar (Sony), Buena Vista (The Walt Disney Company), Twentieth Century Fox (News Corp.), Universal (NBC Universal), and Warner Bros. (Time Warner). They produce, finance, and distribute their own films. They also finance and distribute pictures initiated by independent filmmakers who either work directly for them or have projects 'picked up' after some progress has been made. Smaller, 'independent' production companies feed their (typically less commercially oriented) productions into the established distribution pipelines of larger companies, or have mini-distribution organizations of their own. A third group, the so-called 'mini-majors', which includes MGM, New Line Cinema, Miramax, and Lion's Gate, has become a more significant force in the past decade. Companies in this group generally have production and distribution capabilities, but their activities tend to have less scope (Vogel 2001).

However, exactly how and where to draw the line between these groups is becoming less and less clear. For example, 'mini-major' New Line Cinema is responsible for one of the biggest film 
franchises of all time, the Lord of the Rings trilogy, while 'major' Warner Bros. has established its own 'independent' film subsidiary, Warner Independent Pictures, to produce non-mainstream movies. In fact, it is worth noting that each of the major studios has an autonomous division that is responsible for 'independent' movies. Mergers and acquisitions and, more generally, the emergence of media conglomerates, further blur the lines. Both New Line Cinema and Warner Bros. are part of Time Warner.

One key performance metric for distributors is the movie's U.S. theatrical box-office gross, which in turn is often an indicator of the sales potential in other distribution 'windows' (e.g., global theatrical, home video, and pay television). The importance of this metric reflects the (disproportionally) strong emphasis on revenues instead of profits in the motion picture industry. A movie that grosses more than $\$ 100$ million cumulatively in U.S theatres is typically considered a 'blockbuster'. We expect that:

\section{Box-Office Performance Will Increasingly Depend on a Small Number of Blockbusters}

Studios and distributors hedge their bets by releasing a slate of movies each year. The most promising projects (so-called 'tent pole' or 'event' movies) will generally receive the most attention. These movies often receive the highest production budgets as well as the highest marketing budgets and, critical to a successful theatrical release, a favorable release date. Because the share of revenues captured by blockbuster movies continues to rise, this appears to be a valid strategy. For example, in 2003, 19 movies generated over $\$ 50$ million each at the box office (accounting for 22\% of the year's total), compared with 14 in 1998. Also, 5 movies generated over \$100 million each in theatrical revenues in 2003 (accounting for 14\% of the year's total), compared with 2 in 1998 (MPAA 2004). However, ever-higher investments are required to produce and market such blockbusters. The average 'negative cost' for a movie has increased from less than \$30 million in the early 1990s to nearly \$65 million in the early 2000s; advertising budgets have jumped from roughly \$10 million to nearly \$35 million in the same period (MPAA 2004). In the summer of 2004 alone, Hollywood studios released more than two dozen $\$ 100$ million-plus films (The Wall Street Journal, 2004c). This, in turn, makes distributors ever more dependent on the success of their potential blockbusters, which puts enormous pressure on the industry, and forces studios to find creative ways to turn the release of a movie into an 'event'. If a tent pole movie fails miserably at the box office, it substantially affects a studio's bottom line (an 
infamous example is United Artists, which was virtually bankrupted by the failure of just one movie, Heaven's Gate).

This phenomenon is not unique to the motion picture industry. A general trend towards 'winnertake-all' or 'winner-take-most' markets has been well documented (e.g. Frank \& Cook 1995). Many industries are characterized by the same cycle - a need for successful innovations, which drives ever higher R\&D investments, which in turns fosters a higher need for successful innovations. The pharmaceutical industry is one good example (The Economist 2003). These developments have received little attention from marketing researchers. However, it is crucial for motion picture executives to understand how to cope with this phenomenon, in part by more accurately predicting the success of projects and recognizing blockbusters at an early stage and by more effectively managing the pipeline of projects in development (as discussed in the "Production" section).

At least, the following future research questions emerge:

- Is 'blockbuster' an ex-post or an ex-ante construct? That is, can a movie be validly designated a (potential) blockbuster before or only after its theatrical release? If before, at what stage in the development process?

- How should a studio manage a blockbuster across windows? To what extent and in what ways should a studio adapt its marketing strategies when it becomes clear that a movie is a hit?

- What is the optimal way of releasing a slate of movies, either wide or limited releases, in a highly competitive marketplace?

In light of the above trends, advertising remains a major strategic decision variable for theatrical distributors. We anticipate that:

\section{Distributors Will Continue to Rely on High Advertising Budgets in Releasing their Films, But will Allocate Those Budgets differently and More Evenly Across Media Vehicles}

Distributors spend hefty sums on advertising for their movies. In addition to the nearly $\$ 64$ million in production costs spent on an average movie in 2003, \$35 million worth of advertising directly impacted that movie's bottom line (MPAA 2004). According to Nielsen Monitor-Plus data, overall spending on advertising by the studios and major independents was nearly $\$ 3.3$ 
billion in 2003 (The Hollywood Reporter 2004). Several studies have established a link between advertising expenditures and box-office grosses. Prag and Casavant (1994), Zufryden (1996; 2000), and Moul (2004) all found evidence for a positive relationship between advertising and weekly or cumulative revenues. Lehmann and Weinberg (2000) showed that the level of advertising for a movie is positively correlated with opening strength. Elberse and Eliashberg (2003) found that the positive relationship between advertising expenditures and opening-week revenues is largely due to a second positive correlation between advertising expenditures and the screens allocated to a movie in its opening week. It is plausible that movies that are expected to be popular receive more advertising (Sorenson and Waguespack 2003). As such, it remains largely unclear to what extent and how advertising impacts sales, and therefore if advertising is currently allocated over time in an optimal fashion. An experimental research design, or a modeling approach in which advertising spending is adaptively controlled (e.g., Little 1966), may increase our understanding.

In theory, the amount of advertising necessary to market a movie is inversely related to the amount of word-of-mouth that the movie is likely to generate. That is, marketing campaigns that generate a disproportionate amount of word-of-mouth communication might be able to get away with less mass media advertising spending or may require a less traditional allocation of advertising spending across media types. This relates to the difference between a wide (blitz) and limited release strategy. Word-of-mouth communication is typically critical to the formation of demand. (e.g. Katz and Lazarsfeld 1955). Word of mouth appears to be a particularly important driver of the success of entertainment goods (e.g. Chevalier and Mayzlin 2003), because such goods are often consumed collectively and because they often feature in daily conversations. Movie marketers have pioneered "buzz marketing", for example by giving opinion leaders free access to the product (i.e., inviting them to a free preview) in the hope that it will stimulate positive word-of-mouth. In addition, content-related decisions (such as the inclusion of a particularly graphic scene or the casting of an actor with high star power) as well as joining forces with consumer goods advertisers (e.g., beer) may trigger widespread "free publicity" and awareness for movies. However, studios seem hesitant to rely on micro-marketing, which entails targeting word of mouth spreaders, as a key driver of demand for films. In fact, it seems that the trend among studios is to bet on strong opening weekends supported by mass media advertising to reduce the risk that negative word-of-mouth communication will hurt sales later in a movie's run. Heavy reliance on expensive network advertising (e.g., Super Bowl) deserves further research attention. 
Increasingly, the emergence of Internet-based 'word-of-mouse' communities, where people share opinions on companies, products, and events, is likely to impact word of mouth dynamics (e.g. Dellarocas 2003). A proliferation of online sources that provide information on motion pictures, including chat rooms, Web logs, portals (like Yahoo Movies), recommendation sites (like Moviefone), customer review sections of online retailers (like Amazon), databases (like IMDB), and critics sites (like Rottentomatoes), has made it easy for consumers to find out what others think about a particular movie. Motion picture studios and other players are slowly coming to terms with this phenomenon. Fortunately, online environments also provide excellent conditions for research on word-of-mouth dynamics, and academic researchers are starting to respond (e.g., Chevalier and Mayzlin 2003; Godes and Mayzlin 2004).

Knowledge of the effectiveness of various advertising media vehicles is still limited. Television advertising, in particular in network TV, is the largest investment - it accounts for nearly $40 \%$ of total advertising budgets for new releases. Print advertising, trailers, Internet advertising, radio commercials, billboards and other advertising media together account for another $40 \%$. Nonmedia advertising, including creative services, exhibitor services, promotion and publicity, and market research accounts for the balance of the budget (MPAA 2004). Whether this is an optimal media mix, and how much the optimal mix varies across movies, remains unclear. Given the probable role that word-of-mouth communication plays in driving ticket sales across a movie's entire run, and given the Internet's role in facilitating and disseminating word-of-mouth, it is likely that the Internet's share of total spending will increase. The success of the movie The Blair Witch Project, for instance, is attributed partly to an innovative Internet campaign in which all kinds of fake materials related to the old Blair Witch legend were posted on a website (e.g., alleged diaries of one of the "missing" characters). The site received millions of visitors and the very low budget movie grossed over a $\$ 100$ million in a few weeks. Studios are now often actively working with fan Web sites to increase their control over this medium (Variety 2004c). In addition, given the rise in commercial-free programming, such as cable television and satellite radio, and the increasing use of technologies that allow consumers to skip commercials, such as Digital Video Recorders (DVRs), the share of advertising allocated to broadcast television is likely to decrease.

While total advertising spending is extremely high, studios/distributors appear to make hardly any attempt to increase consumer loyalty across their entire slate of movies. They are paying attention 
to establishing movie franchises around unique movie concepts that spawn sequels and generate revenues in non-theatrical windows (The Lord Of The Rings is a good example). Some directors and actors (e.g., Steven Spielberg and Tom Hanks) have established 'brand equity' in the marketplace. Also, some intellectual properties (e.g., Marvel's superheroes) have a loyal following (Elberse, 2004). However, with the possible exception of Disney and some smaller independent distributors, no studio has managed to establish a strong brand identity among end consumers that covers a substantial part of their entire portfolio of movies. In fact, very few moviegoers know which studios and distributors are behind the movies they watch.

Relevant future research questions include:

- What is the optimal level of advertising expenditures, and how should they be allocated across media vehicles- traditional and non-traditional?

- How do online review sites, movie databases, search engines, and other feedback systems affect movie consumption? How does information about a movie's quality that originates from reputable sources (e.g. critics, festival juries, and award committees) interact with word of mouth created by 'regular' consumers? How does this affect sales?

- To what extent do consumers respond differently to 'official' information that stems from movie studios and to information created by their peers? How do they respond to studios' attempts to manipulate word-of-mouth communication?

- What is an optimal 'buzz' marketing strategy - a campaign that encourages audiences to attend the movie without generating unrealistic expectations that will lead to disappointment and negative word of mouth?

- On what basis should the decision for a limited versus wide opening (i.e. a low versus high number of screens) be made?

- Is there a benefit from building brand equity?

Another strategic decision variable for distributors is the timing of releases. This decision has two dimensions: (1) the theatrical release in the U.S. and in international markets; and (2) the subsequent release in successive distribution outlets. As far as theatrical markets are concerned, studios have traditionally made their movies available first in the U.S. and then, with some delay, around the globe. We anticipate that:

\section{Distributors' Theatrical Release Timing Will Become an Increasingly Important Strategic Decision}


Fueled by the popular media's fascination with "the number one movie" in any given week, a successful opening weekend has become almost a requirement for long-term success across all windows. A movie that fails to open strongly often loses the attention of the media, audiences, and exhibitors. Timing the opening carefully is therefore crucial.

The question of when to release a movie theatrically has already received some attention from researchers. Most studies have focused on the role of competition and seasonality in the U.S. market. Krider and Weinberg (1998) use a game-theoretic model to analyze the high-season release timing of two motion pictures with different drawing power but competing for the same target audience. They examine the trade-off between trying to capture as much revenues during the high season as possible and trying to avoid the competition, which is trying to do the same thing. Krider and Weinberg empirically show that a primary concern in timing releases is 'to stay away from movies that have the same target audience'. Chisholm (2000) models the competition between movies' release timing as a war of attrition. Her findings suggest that studios may be playing a complicated game as they choose holiday releases, and that they balance the benefits of optimizing on a per-film basis with maximizing profits across their stable of film releases. Radas and Shugan (1998) estimate seasonal patterns and find that "seasonality accelerates a motion picture's box office but might not increase the overall potential.”

Einav (2003a; 2003b) looks at both seasonality and competition. He breaks the observed seasonality down into seasonality in underlying demand and seasonality in the quality of movies released. He uses a multinomial logit model to fit weekly market shares for each movie, and then uses the demand estimates to construct and estimate a timing game played by distributors. He finds that observed release patterns are closely aligned to observed patterns in sales, but not to the underlying demand. This implies that distributors could significantly increase their revenues by pushing some of their high-season releases to low-season dates. Building on these insights, one avenue for future research is to consider the timing decision as part of a wider portfolio strategy. Given that a studio's movies compete with each other and with other studios' releases for the attention of audiences and exhibitors, this requires the modeling of a complicated timing game. Work on the introduction of successive generations of new products (e.g., Norton and Bass 1987) is relevant in this regard, but will need to be adapted to the specific context. 
The optimal timing of subsequent releases in the international theatrical markets is another intensely debated issue. International markets are an important and increasing source of revenue. A large majority of Hollywood movies now generate higher revenues overseas than in the U.S. (Variety, 2004a). While some studios have considered (and, in some instances, implemented) the notion of releasing movies first in foreign markets and then in the U.S. market, the timing debate is mostly about whether studios should release movies 'day and date', that is, simultaneously in the global market (Variety 2003c). There has been a gradual trend toward shorter gaps between domestic and foreign theatrical openings. Elberse (2002) reports on interviews with motion picture industry executives which shed light on the complexities of the international release strategy decision-making process as well as on the forces and counter-forces that go hand in hand with simultaneous and sequential releases. Opportunities to save interest on investments, to prevent piracy from cannibalizing revenues, and to capitalize on the 'buzz' that a movie has generated in the U.S., all push distributors toward a simultaneous release strategy. But such practical considerations as the time it takes to subtitle the movie, the cost of additional prints, and the chance to learn from the U.S. performance and adjust marketing strategies for releases in other countries, all push distributors toward a sequential release strategy. In a quantitative examination of movies' box office performance in the U.S. and the five largest European markets, Elberse and Eliashberg (2003) find that there is an association between a movie's performance in the U.S. and its performance in these European markets, and that this is not simply a consequence of the availability of the movie in theaters. They also find that the time lag between releases moderates this relationship, which suggests that the 'buzz' generated in the U.S. market may quickly wear out. This implies that, provided a movie performs reasonably well in the U.S., it is worthwhile to schedule the movie's international releases soon after its U.S. release. Precisely what the optimal time lag is and what local factors, such as the characteristics of the audience, affect the timing still need to be determined.

It follows that some important research challenges are:

- What are the optimal release times across a studio's entire slate of movies?

- To what extent do co-financing deals between major studios impact release dates?

- What are the optimal order of entry and the optimal release timing for movies in theatrical markets around the globe?

- How do the profiles of fans differ across the various national and regional markets and how do these differences affect the optimal timing strategy? 
As far as the timing of non-theatrical windows relative to theatrical windows is concerned, we believe that:

\section{Distributors will Benefit from Shortening the Time between Theatrical and Non-Theatrical Windows - But They are Walking a Fine Line}

The trend towards shorter time lags in theatrical releases around the globe is fueled by another development - the growing importance of non-theatrical windows as a source of revenue. That holds especially for DVDs, which have become the largest revenue window, accounting for roughly \$20 billion in 2003 - twice what is spent on U.S. theatrical tickets (Standard \& Poor's 2004). In fact, it is widely believed that most movies do not break even until they are released on DVD. The sooner movies have completed their theatrical run (in major markets) overseas; the sooner they can be released on video and the investment in the movie can be recouped.

However, timing decisions for non-theatrical windows are complicated - and increasingly so. In general, windowing is determined by the principle of 'the second-best alternative' (Vogel 2001). Films are normally first distributed to the market that generates the highest revenues over the least amount of time. They then 'cascade' in order of revenue contribution down to markets that return the lowest revenues per unit time. Historically, that has meant that theatrical release was followed by pay-cable programming, home video, network television, and finally local television syndication.

But DVDs are capable of generating higher revenue than theatrical tickets over a shorter amount of time, as are other new technologies such as Pay Per View (PPV) and Video On Demand (VOD). This puts pressure on the existing windowing structure, and could cause fundamental shifts in sequencing strategies. Some executives, for example, have hinted at the possibility of having the home video window run at the same time as the pay-cable window (The Wall Street Journal, 2004a). The underlying assumption is that pay-cable will eventually replace video rentals (a declining business with relatively low margins for distributors) but not video sales. In addition, once these technologies are well established, it is not inconceivable that new movies released on PPV or VOD channels prior to their theatrical release, and priced adequately, could be sold to millions of viewers, generating revenues on par with a regular theatrical release. While this scenario may seem far-fetched, vertical integration in the motion picture industry could make such unconventional release strategies more attractive for key players. Focusing on the cable 
television industry, Chipty (2001) finds that integration tends to exclude rivals but does not harm, and may actually benefit, consumers because of the associated efficiency gains.

Some studies on the substitutability versus complementarity of revenue windows have already been conducted. Using telephone survey data, Williams and Shapiro (1985) studied the link between the use of in-home entertainment alternatives and film attendance. Gambaro (2004) examined the relationship between theatrical performance of movies in Italy and their subsequent share of TV network viewership there. It seems particularly worthwhile to investigate the effects of video openings on theatrical moviegoers' behavior. The possibilities of new partnerships and mergers - between theatrical and home entertainment distributors, for example, or between cable TV distributors and content providers - are likely to reduce the time lags between successive movie releases. Existing research on the timing of the video window (e.g., Frank 1994; Lehmann and Weinberg 2000) provides a good starting point.

Several questions need to be resolved so that distributors can make informed timing decisions in this new context:

- What is the likely audience size and revenue per audience member in each revenue window? How much overlap exists between theatrical and non-theatrical consumer segments?

- To what extent are theatrical and non-theatrical windows substitutes or complements (i.e. either negatively or positively affecting each other's revenue potential)? For example, does the availability of DVDs deter people from going to the theater? Does the prospect of being able to see a movie on pay cable, network or syndication television deter people from going to the theater? How much do consumers value 'owning' versus 'renting' content in these settings? How much do they value the social aspect of movie consumption? How time sensitive are consumers? And do the answers to the above questions differ across segments of consumers, across types of movies, and/or across theater segments?

- What windowing strategies maximize studios' revenues and/or profits? More specifically, what revenue windows will remain viable, and in what order can studios best tap them?

- To what extent do optimal launch strategies differ across markets and across distribution outlets? What lessons can be carried over?

We note that arguments can be made for both substitutability (i.e., overlapping consumer segments) and complementarity (i.e., distinct consumer segments) hypotheses - earlier windows can be substitutes in the sense that they cannibalize later sales, and complements in the sense that 
there is spillover of marketing effort and word-of-mouth communication. Given that going to the theater is a different social experience than watching a movie at home, intense concerns about the substitutability of the theatrical window seems misplaced. Nevertheless, knowing the extent to which consumers view these windows are substitutes or complements, and the extent to which that differs depending on the particular movie and the exact timing of windows, can significantly benefit distributors in assessing alternative release plans. This knowledge would be critical even if, as Weinberg (2003) puts it, domestic theatrical releases have become 'loss leaders' for a stream of other products that earn the lion's share of revenues.

While new consumer technologies (e.g. DVD, VOD, HDTV, and DVR) are starting to have a significant impact on theatrical distribution strategies, the impact of digital technology on this stage of the value chain is much broader - and several issues deserve further attention from researchers. We expect that:

\section{The Benefits of Digital Technology will Continue to Outweigh the Costs for Distributors - At Least for the Foreseeable Future}

Advances in digital technology hold a number of opportunities and threats for studios. They nay also change the types of movies made (Tyagi 2004). The threats mostly involve movie piracy. Illegal reproduction of copies has become easier and cheaper, while the Internet also enables the sharing of electronic copies on a global scale. Consequently, analogous to developments in the music industry, piracy is widely regarded as the key threat to movie distributors' business models (e.g., Deloitte 2004). The MPAA (2003) valued global piracy at $\$ 3.5$ billion in 2003, and the problem has received widespread attention in the popular press. Studios are fighting the threat of piracy via court battles and by educating and inducing consumers to use legal alternatives, particularly the Internet sites established by studios themselves (e.g., Movielink). So far, these activities seem to have had limited success.

There is evidence that piracy is not the significant threat the entertainment industry believes it to be. Peitz and Waelbroeck (2003) review economics literature on the piracy of digital products. A recent music industry study by Peitz and Waelbroeck (2004), based on the results of a crosssectional analysis, concluded that "internet piracy played a significant role in the decline in CD sales in 2001, but can hardly account for the subsequent drop in 2002". A more comprehensive

time series analysis for the same industry did not find a significant negative effect of file sharing 
on music sales in a 17-week period in 2002 either (Oberholzer and Strumpf 2004). Similarly, the extent to which piracy affects the behavior of moviegoers and consumers of movies in other windows remains to be seen. It is not known whether a dollar lost to piracy is one the distributors could have collected, e.g. in theater tickets or DVD sales.

Piracy can be regarded as a separate window (albeit one that generates no income for studios/distributors), or even as a set of windows with varying quality (e.g. ranging from theatrical showings taped with a camcorder to copies made directly from a DVD). Seen in that light, questions that were raised in the previous section also help to frame the debate about the impact of movie piracy:

- Does the 'movie piracy' window substitute or complement the consumption experience for other release windows? To what extent are consumers willing to pay more for legal alternatives?

- What drives movie pirates? What are the determinants of downloading and file sharing behavior? Are some movies more amenable to piracy?

- How can the impact of movie piracy be quantified? How does it affect production and innovation?

- Do the answers to these questions differ across territories or cultures (e.g., Husted 2000)?

Pirated movies certainly seem to be a poor substitute for the theatrical experience. Most industry insiders appear more concerned about the impact of piracy on the sale of DVDs, an obvious comparable product, than on theatrical revenues (see Weinberg 2003 for a more comprehensive discussion). Consumers, they fear, might perceive high-quality copies made directly from a digital version (e.g. a DVD screener) to be particularly good substitutes for legitimate DVDs. However, to our knowledge, there is not yet any empirical evidence for this view.

Opportunities related to digital technology in the distribution stage lie in creating trailers and other necessary content for promotions and selling efforts, but mostly with what has been referred to as 'digital cinemas' - the distribution and projection of movies in a digital format, without the need for actual film prints. This development offers studios increased flexibility and substantial cost savings. For example, if all cinemas were to operate with digital projectors tomorrow, actual movie prints (costing about $\$ 2,000$ each) would become obsolete. Studios would save about $\$ 4$ million for the average movie in its U.S. release alone, and a multiple of that in foreign territories. The Boston Consulting Group (2002) has estimated the potential annual savings to amount to 
over $\$ 1$ billion annually in the U.S. alone, with roughly $80 \%$ going to the distributor (and the remainder to the exhibitor), and over $\$ 1.5$ billion internationally. And because exhibitors will have to bear the lion's share of the investments in upgrading to digital cinemas, these are important benefits for studios. However, conflicting standards slow down the penetration of digital cinemas and studios might be hesitant to push the envelope on digital cinemas because it implies their loss of control over exhibitors (digital technology gives exhibitors more scheduling flexibility, as discussed in the "Exhibition" section below) and might allow intermediaries to enter the marketplace and erode the studios' dominant position.

Key future research avenues regarding digital cinemas are:

- What do players in the value chain stand to gain and lose from digital cinema initiatives, and how can they be incentivized to adopt new distribution and projection technologies?

- What are the key strategic drivers of emerging incompatible technology standards and what role across the globe do they play?

- How should relevant players manage the transition to a fully digital cinema landscape? What business models are appropriate in this new environment?

\section{EXHIBITION}

Practitioners consider the theatrical performance of a movie in the U.S. to be a critical driver of its success in subsequent release windows. One insider commented: "Theatrical exhibition is the major factor in persuading the public what they want to see, even if that public never sets foot inside a motion picture theater. And how well and how long a picture plays in theaters has everything to do with its value in other markets" (Daniels, Leedy and Sills, 1998, p. 34). The 'buzz' that studios generate for movies prior to and during their theatrical release - a combination of advertising , media attention, and word-of-mouth communication - is widely believed to be the main reason for this phenomenon.

To date, the adoption of home widescreen television does not appear to have had a significant negative impact on aggregate behavior. Because of improvements in theatrical facilities such as multiple screens, more comfortable seating, improved sound and, and a range of ancillary services, theater attendance in 2003 is at record levels in the U.S. and overseas (e.g. Doyle 1998; Standard \& Poor's 2004). The growth in the exhibition sector has been mainly in 'multiplexes' 
(facilities with 8 to 15 screens) and 'megaplexes' (those with more than 16 screens). In 2003, such facilities accounted for about $35 \%$ of the more than 6,000 theatrical facilities in the U.S. These larger facilities allow exhibitors to use their real estate more efficiently and to offer a wide variety of movies to consumers. In addition, shopping malls show an increased interest in allocating floor space to (themed) megaplexes (The Wall Street Journal, 2005).

However, if the U.S theatrical exhibition business does not address future trends such as increased adoption of more affordable large screens digital home theaters as well as increased time spent by consumers between the age of 12 and 34 on the Internet, playing videogames, and use of their cell-phones it will face serious challenges. Moreover, the theatrical exhibition business is characterized by a number of operational inefficiencies. One fundamental question is:

\section{Is the U.S. Theatrical Motion Picture Market Still Over-Screened?}

The U.S. theatrical exhibition landscape comprises major theater chains and independent exhibitors. Many industry insiders have argued that, during the 1990s, and possibly later, the U.S. market has been 'over-screened', i.e. that the number of theater screens was too high for the number of movie-goers, their movie-going frequency, and the supply of movies. Some statistics support this hypothesis. An examination of the total number of screens and theaters over time suggests that the U.S. exhibition industry began a trend downward adjustment in 2000, in response to a halt in admissions growth. Growth rates in the number of screens between 1997 and 1998 (8 \%) and between 1998 and 1999 (9\%), for example, are higher than the corresponding growth (and decline) rates in admissions (6.7\% and $-1.0 \%$, respectively). This gap brought the debate on over-screening to the forefront. While the number of screens rose from roughly 23,000 in 1989 to 37,000 in 1999 (a 62\% growth rate), admissions grew at a much lower rate of 17\%, from 1.26 billion to 1.47 billion. The exhibition industry responded by lowering the number of screens from its peak of 37,396 in 2000 to 36,764 in 2001, 35,280 in 2002, and 35,786 in 2003. Using an econometric modeling approach, Elberse \& Eliashberg (2003) showed that the relationship between number of screens and revenues for movies released in 1999 and 2000 was concave for the U.S. but convex for four major European markets. This, too, indicates that, at that time, the U.S. was 'over-screened' and other markets were largely 'under-screened'.

However, the situation may not be as clear-cut as it seems. Davis (2003) empirically studied the extent and nature of exit, entry, and revenue cannibalization in the U.S. exhibition sector during 
the 1990s. Contrary to common belief, he argued that the problem of overcapacity of screens was not that severe, and that the market participants did not act irrationally when making entry or exit decisions. Instead, he revealed that new rival entrants succeeded in 'stealing' incumbents' revenues, and that high-quality theaters managed to expand the market (see Cleeren, Dekimpe, and Verboven (2005) for an analysis of market entry and the impact on intra and inter-channel competition in a related sector, the video rental industry). Davis (2001) developed supply and demand models to derive the exhibitor's optimal scale of operations. He investigated the relationship between theater characteristics (price and quality); the distance consumers have to travel to theaters, and their demand for movies. His results suggest that theaters are often local monopolists, and that "business stealing effects" across theaters are small and decrease significantly with distance, and that theaters are likely to under-provide movie screens relative to a socially optimal number. The strong demand for movies (and thus screens) in high-season periods, and the trend to use theaters increasingly for non-movie events in low-season periods, may also have lessened the problem.

Relevant future research questions include:

- What is the equilibrium number of screens in a country or region? One rule of thumb used in the industry is that when the estimated movie-going frequency is 5.5 movies per year per person, one screen for every 10,000 people is needed. Research is needed to evaluate this and other heuristics.

- What measures (other than the commonly used 'screens per 1 million inhabitants') can be used to evaluate the extent to which a country/regional market is over/under screened?

- What determines the optimal level of screens? How will it be affected by changes in home consumption of movies and other leisure activities?

- How can one measure the extent to which two competing theaters offer similar/dissimilar assortments of movies?

The answers to the above questions depend on the number of major players in the market, who they are, and what business strategies they adopt. We expect that:

\section{The Exhibition Market will Become More Concentrated, More Integrated (Through Mergers and Acquisitions), and New (More Sophisticated) Players will Emerge}


The exhibition industry has been undergoing major structural changes recently. A change in the level of concentration can be illustrated by comparing the current landscape with that of a decade ago. Back in 1994, the five major U.S. exhibition chains (United Artists Theaters, Carmike Cinemas, Cineplex Odeon, AMC Entertainment, and General Cinema Theaters) owned over 8,000 screens, over $30 \%$ of the total. In 2003, ownership is more concentrated. The top five exhibition chains (Regal Entertainment Group, AMC Entertainment, Carmike Cinema, Cinemark U.S.A., and Loews Cineplex Entertainment) own $45 \%$ of the screens (and $25 \%$ of the sites). It is conceivable that the U.S. will become even more concentrated in the near future, and thus more like countries such as the UK, where the leading five exhibitors owned more than $60 \%$ of the screens in 1998.

Exhibitors have increased their market shares through horizontal integration (mergers and acquisitions) and through the selection and development of real estate. Various factors influence new-site selection, most of them related to demographics and economics. Some particularly business-savvy established players have become very powerful. One example is Regal Entertainment, which has emerged as the biggest player under the leadership of Philip Anschuts. It comprises Regal Cinemas, United Artists Theatres, and Edwards Theatres, and now operates more than 6,000 screens - nearly one sixth of the total - at 562 locations in 39 states. However, niche players are likely to play an increasingly important role in the future. Examples include Game Works, a Los-Angeles-based game arcade/restaurant/cinema chain, and Muvico Theaters, a Florida-based chain of megaplex theaters and entertainment centers built distinctly in selected markets. Exhibitors often operate as local monopolists or duopolists, which can severely limit the range of films on offer. Eliashberg (2004) provides more details on major and niche exhibitors and gives some examples of duopolistic markets.

In a study on geographic regions, and with public policy implications, Davis (2005) examined price differentiation across markets as well as the relationship between local competition and admission prices. He found that ticket prices depend on the presence of other theaters within the local market, but that the effect is relatively small. The reduction in price resulting from the presence of a nearby rival theater is smaller than that resulting from the presence of a theater owned by the same chain. This suggests that fears of increasing admission prices due to mergers and acquisitions are misguided. 
Another major structural change in the market involves vertical integration. In 1948 a suit that was previously filed by the Department of Justice led to "the Paramount decrees" which prohibited vertical integration by distributors. In the 1980s, however, the regulation was relaxed, allowing distributors to have exhibition interests as long as their share of the total screen capacity remains low.

Future research avenues are:

- What is the desired level of concentration in the exhibition sector? Does that differ across countries?

- How should investors value an exhibition chain? How many screens should distributors be allowed/plan to own?

- How should exhibitors select a geographical area for theatrical facility development?

- How can exhibitors initiate a niche or innovative-entry strategy?

- What constitutes an effective portfolio of entertainment assets that include, among other assets, one or more theaters?

The emergence of powerful and niche players in the exhibition sector is likely to change the rules of the game with distributors. We believe that:

\section{The Contractual Arrangements between Distributors and Exhibitors are Inefficient and will Change - So will Admission Pricing Strategies}

Distributors decide whether to negotiate directly with theaters or to solicit bids. Most contractual arrangements between the distributor and the exhibitor stipulate a minimum playing time and an agreement as to how the box-office receipts are to be shared. For many major movies, a slidingscale agreement is used. It has two components: an after house allowance ('nut') split, and a guaranteed minimum ('floor'). The house allowance is recognition, on the distributor's part, that the exhibitor incurs expenses in running the facility (e.g., rent, insurance, and maintenance). Both the split and the floor are typically such that the distributor's share is high in the first few weeks and it declines as the movie's run proceeds (Vogel, 2001). The specific values of the split, floor, and the rate at which they slide are determined by the relative power of the two parties. The exhibitor's key power bases appear to be the total number of screens it owns, their location, and the relative shortage (or surplus) of screens available at the time, while the distributor's key power bases appear to be the expected success of the particular movie and the amount of 
promotional support the distributor is willing to commit. While the exhibitor's share of the ticket sales increases during the movie's run, the distributor normally withdraws advertising support after the first two to three weeks. This leaves the exhibitor with a dilemma: whether to opt for a small share from a larger pie (by playing a newly released movie) or a large share from a smaller pie (by sticking with an ongoing movie).

Surprisingly little work has examined the contractual arrangements between distributors and exhibitors; this is a promising area for research. Some notable efforts include Filson et al. (2005), who demonstrated empirically that movie exhibition contracts typically reflect the uncertainty of demand rather than an information advantage for studios. Raut, Swami, Lee and Weinberg (2004) examined the profit impact of various types of channel contracts by using the SilverScreener (Swami at al 1999) model to mimic a situation in which an exhibitor acts 'intelligently' with respect to screen scheduling. Mortimer (2004) has examined contracts in the video rental industry.

An analysis that concentrates on the practice of 'block-booking', whereby distributors sell motion pictures as a package, is also warranted. This practice, which can be traced back to the early 1920s (Lewis 1933), was banned by the U.S. Supreme Court on the grounds that it was unfair to the exhibitor - it forced them to play movies that turned out to be unsuccessful. However, in a recent study, Hanssen (2000) argued that the block-booking arrangement is not an unfair practice, but rather a helpful tool in the selling of motion pictures and other products that need to be provided cheaply in considerable quantities. Additional analyses might provide further evidence that, at least in the short run, implicit 'block-booking' of films, which entails sending a threatening signal to the exhibitors that unless they provide screens to the less successful movies they will not receive favorable terms in future potential blockbusters, is likely to prevail.

The determination of the admission price - legally in the hands of exhibitors, but closely monitored by distributors - also raises an interesting contracting problem. A theater's ticket prices are generally uniform across titles and over time (with the exception of matinees). Exhibitors might prefer a lower price in order to compete more effectively with other exhibitors. Lower ticket prices may increase attendance and consequently the revenues from concessions, a revenue source not shared with the distributor. Distributors naturally prefer a higher ticket price (Caves 2001). Some distribution executives have actively sought to increase revenues by making the price structure variable. For example, several years ago, Mr. Edgar Bronfman, then CEO of 
Universal, put forward an innovative but controversial ticket pricing idea (The Hollywood Reporter 1998). Believing that 'event films need event ticket prices', he suggested differentiating admission prices of movies on such bases as production budget and star power. In addition, he argued that the demand for movies in their opening weekend is inelastic, and hence, there may be room for temporal price discrimination. Such a pricing scheme could increase the size of the pie that the distributor and exhibitor share, benefiting both. The industry has not adopted these or other alternative pricing schemes for various reasons, including a lack of objective criteria for determining the 'right' price and potential resistance from creative talent. But it is remarkable that theaters maintain uniform ticket prices, given that the wholesale price at which they rent movies from studios varies considerably with the appeal of the movie and the time since release (Weinberg 2003).

The question of whether ticket prices will and should remain uniform across titles and over time is a deserving research topic which has started to receive some attention. Orbach and Einav (2001) identified flaws in the existing pricing policy and explored possible justifications for uniform prices. They concluded that several factors contribute to the persistence of this inefficient pricing policy: the likelihood that consumers will perceive price variation as unfair; movies' short life cycle (which limits exhibitors' opportunities to adjust prices once the uncertainty concerning a movie's popularity is resolved); diverging interests of distributors and exhibitors; and the instability of demand. Orbach (2004) provides a more comprehensive overview of industry pricing. Research on pricing in relation to potential service bundles offered by cinemas (e.g. dinner and a movie) also seems worthwhile.

Some particularly relevant future research avenues are captured by the following questions:

- Is the currently employed contract fair, given the present situation in the industry?

- How should the contractual arrangement between the distributor and the exhibitor be redesigned to fit the new realities of the marketplace?

- What should the optimal sliding-scale agreement be? How can the welfare of the supply chain be improved?

- What is an 'event' movie and what sort of unique strategic considerations does it deserve?

- What are appropriate admission prices and pricing policies? Specifically, what are efficient and implementable price discrimination policies?

- What are the properties of pricing equilibria adopted by competing exhibitors? 
There are other strategies exhibitors can use to improve their profitability. In our opinion:

\section{Exhibitors Seeking to Effectively Manage their Business will Face a Highly Complex Strategic Space}

Managing an exhibition chain involves juggling a variety of tasks, including selecting, acquiring, and developing sites; hiring and training personnel; advertising and promoting theaters and films; setting prices for tickets and concessions; and, of course, procuring and scheduling films. Procuring films involves a range of decisions, including what type of movies (in terms of genres, ratings, stars, and other characteristics) to play in theaters so as to maintain a competitive positioning vis-à-vis other theaters targeting the local audience, and how far in advance to book selected movies. The exhibitor's procurement strategy forms the basis of a macro-scheduling plan, in which the movies are allocated to different screens. The plan is adjusted as actual demand for those movies is revealed.

Research on the procurement and macro-scheduling of films has taken the perspective either of the exhibition industry as a whole or of an individual exhibitor. Research on the former has generally been descriptive; research on the latter has tended to be more normative. Both perspectives have contributed valuable knowledge to a topic that is crucial for exhibitors, who are faced with the challenge of scheduling a large number of more or less unique products with relatively short life cycles. This task is particularly difficult in 'high season' periods when competition for screen space is intense.

Taking an industry perspective, Jones and Ritz (1991) have modeled the evolution of the demand for movies from consumers and the supply of screen 'shelf-space', while accounting for the effect that exhibitors' allocation of screens has on consumers' adoption of particular movies. Taking this one step further, and considering a two-way endogenous relationship, Elberse and Eliashberg (2003) have studied the adaptive behavior of both exhibitors and audiences in the U.S. and other markets. Their empirical analyses revealed that variables such as movie attributes and advertising expenditures, typically assumed to influence audiences directly, mostly do so indirectly, through their impact on exhibitors' screen allocations.

Focusing on the level of individual exhibitors, Swami, Eliashberg and Weinberg (1999) introduced a decision support model, 'SilverScreener', to assist multi-screen exhibitors in 
selecting and macro-scheduling movies over a fixed planning horizon so as to maximize the exhibitors' cumulative profit. Their model considers two phases - movie selection and adaptive scheduling. They conducted an ex-post analysis for a six-screen theater in New York, examining the facility's profitability over a twenty-seven week period in 1989, based on publicly available data and under conventional assumptions concerning house allowance, sliding shares, and concession profits. They showed that the exhibitor could have increased the theater's profitability nearly $40 \%$ by running fewer movies for longer periods, and could have increased the facility's profitability by over $120 \%$ by procuring movies from a larger set of movies running elsewhere in the country.

The SilverScreener model has been implemented as an ex-ante planning tool by an exhibition circuit (Pathé Cinema) in the Netherlands, first for one of its theatrical facilities (Eliashberg, Swami, Weinberg, and Wierenga, 2001) and later for multiple facilities, each having multiple screens (Eliashberg, Swami, Weinberg and Wierenga, 2005). The model has contributed to an improvement in the exhibitor's profitability.

Swami, Puterman and Weinberg (2001) considered the adaptive component of the macroscheduling challenge under a stochastic environment as an optimal replacement problem. They employed a Markov Decision Process model. In their application, which focused on a single exhibitor managing a single-screen theater, the exhibitor observes the movie currently playing, its length of play, and the box office rankings of all movies that could be chosen to replace it. The exhibitor has to decide whether or not to replace the movie and if so, with which available film.

Eliashberg, Jonker, Sawhney and Wierenga (2000) developed and implemented a pre-release market evaluation model for motion pictures, providing insights that are useful to both exhibitors and distributors. The model, MOVIEMOD, is designed to generate box-office forecasts and to support the strategic release decisions (number and type of screens as well as advertising) for a new movie after the movie has been produced, but before its national release. 'Consumer clinics' provide the necessary data. The researchers illustrated the value of MOVIEMOD in two applications: a pilot study conducted in the United States; and a full-fledged implementation conducted with cooperation of the movie's distributor and exhibitor in the Netherlands. The latter led to a modification of advertising and weekly screen scheduling plans for the movie Shadow Conspiracy - and consequently to an improved performance. 
A related question is whether there is room for additional improvements in exhibitors' profitability by 'micro-scheduling' movies already selected for a given theater, that is, by determining the optimal slot for movies on a given day of the week. This involves predicting the box-office performance of movies at different time slots within the day and optimizing the schedule under various constraints, such as that no two movies can start at the same time, that preparation time is required between showings, and that the facility needs to open and close at certain times. Eliashberg, Miller, Swami, Weinberg, and Wierenga (2003) have presented preliminary work and some results in this area. One open issue that deserves attention is how to integrate macro- and micro-scheduling with the planning of other activities that the exhibition facility can be used for (e.g., advertising, sports events, and conferences). That is, how can exhibitors best make the move from running a theatrical facility to managing a portfolio of entertainment assets?

Although managing movie theaters increasingly encompasses a number of new activities aimed at increasing the loyalty of customers, it appears that opportunities to increase loyalty remain largely untapped. Consumers follow different decision-making processes in selecting which movie to watch, in which theater, and at which time. We can distinguish two different behavioral processes: (1) movie-first-theater-second, and (2) theater-first-movie-second. Theater circuits have begun efforts to induce more consumers to adopt the theater-first-movie-second heuristic. AMC Entertainment, for example, has a program called 'Movie Watcher' which provides moviegoers various benefits including free tickets, concessions, and entertainment news. The program has been designed to create loyalty to a particular theater circuit and, possibly, to a particular site. Exhibitors' services range from usual marketing and advertising efforts to the servicing of perks such as 'after-movie mints' and 'ushers who clean the snow from windshields' (The Los Angeles Times, 2002).

Future research may focus on the following issues:

- How can movies attendance best be understood as a collective decision-making process?

- What is the value of various customer relationship management (CRM) programs for exhibitors? More specifically, to what extent can the loyalty programs help to improve customer acquisition and retention?

- What is the effectiveness of various promotional tools? How can this effectiveness be continually assessed? 
- What is the impact of the optimal exhibitor's profits on the entire channel's profit? On DVD sales?

- What role do layout, design, and atmospheric marketing play on consumers' enjoyment of the theatrical experience?

In regard to the last issue, the American Marketing Association (2004) defines the concept 'store atmosphere' as the affective (emotional) and cognitive states consumers experience in a store, but may not be fully conscious of when shopping. Research in this area has examined the impact of location, store design, layout, shape, size, product display and merchandise assortment, color, and lighting on consumer perceptions of the store, mood, shopping behavior, and the overall entertainment experience (e.g. Kotler 1973-4; Bellizi and Robert 1992, Lewison 1994, Levy and Weitz 2001). Similar issues can be studied, with appropriate modifications, in a megaplex setting.

Rapid developments in digital technology may provide the necessary infrastructure for new applications and are likely to affect exhibitors. We conjecture that:

\section{The Costs of Digital Technology will Continue to Outweigh the Benefits for Exhibitors - At Least for the Foreseeable Future}

Advances in new digital technologies are likely to present opportunities as well as threats to the exhibition industry. In addition to the implications of the surge in illegal file sharing through peer-to-peer networks (as discussed in the 'Distribution' section), the rise of 'digital cinemas' may have far-reaching consequences for exhibitors. Digital cinemas are a means of projecting a moving image without using a reel of film. It provides a superior image and sound quality that does not deteriorate with time and multiple showings - a common problem with analogue movie

prints. The market potential of digital cinemas is a much-debated issue. Based on a survey among industry insiders, Screen Digest (2002 p. 43) reported that "a clear majority of respondents think that at least $40 \%$ of European screens will be digital by 2010". However, other sources project adoption levels that are much lower (e.g., see the Boston Consulting Group (2002) for a comprehensive overview of industry thinking).

The advantages of digital technology for producers and distributors are clear: it can substantially reduce the costs of prints and distribution. It also offers important opportunities to exhibitors: a means to enhance the customer experience (and, consequently, to charge higher ticket prices); 
costs savings (e.g., print's theater preparation); alternative and flexible programming possibilities (such as live events, games, interactive films, and business conferences); and even new advertising possibilities. For example, Regal Entertainment has introduced a 20-minute 'preshow' loaded with ads - tailored to local audiences - at its 27 theaters in Philadelphia (The Philadelphia Inquirer, 2003).

However, digital cinema technology also has important downsides for exhibitors. The highest hurdle is the investment in digital projectors (\$100,000-150,000 per screen), expected short lifespan, facilitating technology (e.g. data storage and satellite dishes), and operational and service support. It is not clear under what circumstances this investment would be worthwhile for exhibitors - research is much needed.

Future research opportunities can be summarized as follows:

- What are the advantages and disadvantages of advances in digital technology for cinema exhibitors? How can they be captured in an economic analysis?

- What is the most appropriate response for exhibitors? What opportunities should be pursued, and in what order? How can cinema operators best manage the transition to a fully digital cinema landscape? What partnerships/alliances should be considered?

- What is the impact/effectiveness of other digital uses such as cinema advertising? How does it vary by demographics? By culture?

\section{CONCLUSION}

We have discussed what we believe are some of the most critical issues for the motion picture industry. We have divided our assessment into three sections corresponding to the stages of the value chain for motion pictures - production, theatrical distribution, and exhibition. However, as our analysis indicates, most (if not all) of the issues are inherently linked. Even though our review is undoubtedly (and unavoidably) subjective, numerous interactions with practitioners and a thorough reading of the trade literature lead us to believe that we have covered the key managerial issues. Moreover, we believe that research on consumer movie-going behavior is critical in addressing many of our proposed research directions ( e.g., how do online review sites, movie databases, search engines, and other feedback systems affect movie consumption? How 
does information about a movie's quality that originates from reputable sources interact with word of mouth created by 'regular' consumers? How does this affect sales?).

But other over-arching issues also deserve attention. For example, we are not aware of any research that takes an industry perspective and addresses such general questions as: What is the nature of the power structure in the industry? How has it changed over time? What are its key determinants? What role will each player have in the future? How can media conglomerates best manage their motion picture assets and businesses? How can they find synergies with other assets? Knowledge of these 'bigger-picture' issues will not only be interesting in its own right, but will also help frame potential studies on the managerial issues we discuss.

Technological advances emerge as an important driver of the research avenues that we propose. Technology has always played a major role in the evolution of the motion picture industry but today - more than in the past - technological developments seem to be integral to all stages of the value chain. It is easy to underestimate the implications - we only need to remember an infamous statement by H.M. Warner in 1927, near the end of the silent era: "Who the hell wants to hear actors talk? They're silent the way they should be!" The digital age has just begun, and its ultimate effects on film production, theatrical distribution and exhibition, and non-theatrical media such as television, video, the internet, and mobile devices remain largely unknown. It therefore seems wise to take a broad research perspective on the motion picture industry. Motion pictures come in many formats and industry boundaries are increasingly difficult to draw as more industries (such as finance, cable, telecom (in particular mobile), fast food, consumer electronics, and information technology) assume a role in the development, distribution, and exhibition of motion pictures. Therefore, new metrics of success are needed, while current knowledge of marketing strategies, for example the role of the number of opening screens on the success of the movie, needs to be re-examined. Consumer behavior within the domain of motion pictures (in all their formats) is critical for the development of new metrics; this, too, is an important avenue for research.

We find it encouraging that some research on managerial issues has started to make an impact on business practices, particularly in the exhibition domain. However, as our review also demonstrates, much more work is needed to comprehensively tackle the most pronounced challenges facing motion picture managers. We hope that our review provides the starting point for such research. 


\section{REFERENCES}

Albert, Steven (1998). Movie Stars and the Distribution of Financially Successful Films in the Motion Picture Industry. Journal of Cultural Economics, 22, 249-270.

American Marketing Association (2004). Dictionary of Marketing Terms. www.marketingpower.com

Austin, B. A. (1989). Immediate Seating: A Look at Movie Audiences. Belmont, CA: Wadsworth.

Austin, B. A. (1986). Motivations for Movie Attendance. Communication Quarterly, 34(2), 115126.

Bajaj, Akhilesh, Sunder Kekre, and Kannan Srinivasan (2004). Managing NPD: Cost and Schedule Performance in Design and Manufacturing. Management Science, 50(4), 527536.

Barnes Brooks (2004). Wright's Hollywood Script. The Wall Street Journal, December 22, p. B1. Bayus, Barry (1997). Speed-to-market and New Product Development Tradeoffs. Journal of Product Innovation Management, 14, 485-497.

Bayus, Barry, S. Jain, and Ambar Rao (1997). Too Little, Too early: Introduction Timing and New Product Performance in the Personal Digital Assistant Industry. Journal of Marketing Research, 34, 50-63.

Becker, B. W., Brewer, B., Dickerson, B., \& Magee, R. (1985). The Influence of Personal Values on Movie Preferences. B. A. Austin (Editor), Current Research in Film: Audiences, Economics, and Law (Volume 1) (pp. 37-50). Norwood, NJ: Ablex.

Bellizi, J.A., \& E.H. Robert (1992). Environmental Color, Consumer Feelings, and Purchase Likelihood. Psychology \& Marketing, 9(5) September-October, 347-363.

Blowers, G. H. (1991). Psychological Approaches to Film Audience Research: A Critique. B. A. Austin (Editor), Current Research in Film: Audiences, Economics, and Law (Volume 5) (pp. 56-67). Norwood, NJ: Ablex.

Boor, M. (1992). Relationships among Ratings of Motion Pictures by Viewers and Six Professional Movie Critics. Psychological Reports, 70, 1011-1021.

Boston Consulting Group (2002). Digital Cinema Primer. March 12, 2002.

Burke, Raymond R., Arvind Rangaswamy, Jerry Wind and Jehoshua Eliashberg (1990). A Knowledge-Based System for Advertising Design. Marketing Science, 9 (3), 212-229.

Caves, Richard E. (2001). Creative Industries: Contracts between Art and Commerce. Harvard University Press, Cambridge: MA 
Chevalier, Judith A. and Dina Mayzlin (2003). The Effect of Word of Mouth on Sales: Online Book Reviews. NBER Working Papers 10148, National Bureau of Economic Research.

Chipty, Tasneem (2001). Vertical integration, market foreclosure, and consumer welfare in the cable television industry, The American Economic Review, 91 (3), 428-453.

Chisholm, Darlene C. (1997). Profit-Sharing Versus Fixed-Payment Contracts: Evidence from the Motion Pictures Industry. The Journal of Law, Economics \& Organization, Vol. 13, No. 1, pp. 169-201.

Chisholm, D. C. (2000). The War of Attrition and Optimal Timing of Motion-Picture Releases. Working Paper, Lehigh University, (July 2000).

Cleeren, Kathleen, Marnik G. Dekimpe and Frank Verboven (2005). Intra- and Inter-Channel Competition in Local Service Sectors. Working Paper.

Cohen, Morris A., Jehoshua Eliashberg and Teck Hua Ho (1996). New Product Development: The Performance and Time-To-Market Tradeoff. Management Science, 42(2), 173-186. Collins, Alan, Chris Hand and Martin C. Snell (2002). What Makes A Blockbuster? Economic Analysis of Film Success in the United Kingdom. Managerial and Decision Economics, 23 (6, September), 343-354.

Crawford, M., and Di Benedetto, A. (2003). New Products Management. McGraw-Hill, Boston. Cuadrado, M., and Frasquet, M. (1999). Segmentation of Cinema Audiences: An Exploratory Study Applied to Young Consumers. Journal of Cultural Economics, 23(4), 257-267.

D'Astous, A., and Touil, N. (1999). Consumer Evaluations of Movies on the Basis of Critics' Judgments. Psychology \& Marketing, 16(8), 677-694.

Dahan, Ely and John R. Hauser (2002). The Virtual Customer. Journal of Product Innovation Management, 19 (5), 332-353.

Danan, Martine (1995). Marketing the Hollywood Blockbuster in France. Journal of Popular Film and Television, Fall, 23, 3, 131-140.

Daniels, Bill, David Leedy, and Steven D. Sills (1998). Movie Money: Understanding Hollywood's (Creative) Accounting Practices. Silman-James Press, Los Angeles, California.

Davis, Peter, (2001). Spatial Competition in Retail Markets: Movie Theaters. Working Paper, London School of Economics.

Davis, Peter, (2003). Entry, Cannibalization and Bankruptcy in the U.S. Motion Picture Exhibition Market. Working Paper, London School of Economics.

Davis, Peter, (2005). The Effect of Local Competition on Retail Prices: The U.S. Motion Picture Exhibition Market. Journal of Law and Economics (forthcoming). 
De Silva, I. (1998). Consumer Selection of Motion Pictures. B. R. Litman The Motion Picture Mega-Industry. Needham Heights, MA: Allyn \& Bacon.

De Vany, A., \& Walls, W. D. (1996). Bose-Einstein Dynamics and Adaptive Contracting in the Motion Picture Industry. The Economic Journal, 106(November), 1493-1514.

De Vany, A., \& Walls, W. D. (1997). The Market for Motion Pictures: Rank, Revenue, and Survival. Economic Inquiry, 35(4 (October)), 783-797.

De Vany, A., \& Walls, W. D. (1999). Uncertainty in the Movie Industry: Does Star Power Reduce the Terror of the Box Office? Journal of Cultural Economics, 23(4), 285-318.

De Vany, A., \& Walls, W. D. (2000). Private Information, Demand Cascades, and the Blockbuster Strategy. Working Paper, Department of Economics, University of California at Irvine, December 8, 2000.

De Vany, A., \& Walls, W. D. (2002). Does Hollywood Make Too Many R-rated Movies? Journal of Business, 75,3, 425-451.

Dellarocas, Chrysanthos N. (2003). The Digitization of Word-of-Mouth: Promise and Challenges of Online Reputation Systems. Management Science, October.

Deloitte (2004). Pirates: Digital Theft in the Film Industry. UK: Deloitte \& Touche LLP. [www.deloitte.co.uk].

DeMaday, A. (1929). An Enquiry Respecting the Cinematograph Made in the Schools of Neuchatel, Lausanne, and Geneva. International Review of Educational Cinematography, November/December, 531-522 \& 638-667.

Desai, Mihir A., Gabriel J. Loeb \& Mark F. Veblen (2002). The Strategy and Sources of Motion Picture Finance. Harvard Business School Note, 9-203-007. November 14, 2002.

Ding, Min and Jehoshua Eliashberg (2002). Structuring the New Product Development Pipeline. Management Science, 48(3), March, 343-363.

Dodds, J. C., \& Holbrook, M. B. (1988). What's An Oscar Worth? An Empirical Estimation of the Effects of Nominations and Awards on Movie Distribution and Revenues. B. A. Austin (Editor), Current Research in Film: Audiences, Economics, and Law (Volume 4) (pp. 72-88). Norwood, NJ: Ablex.

Doyle, Barry (1998). Return of the Super Cinema. History Today, Vol. 48, Issue 2 (February), pp. 2-5.

EAO (2003). Focus 2003: World Market Film Trends. European Audiovisual Observatory. [www.obs.coe.int]

Edwards, D. A., \& Buckmire, R. (2001). A Differential Equation Model for North American Cinematic Box-Office Dynamics. IMA Journal of Management Mathematics, 12, 41-74. 
Einav, Liran (2003a). Gross Seasonality and Underlying Seasonality: Evidence from the U.S. Motion Picture Industry. SIEPR Discussion Paper No. 02-36

Einav, Liran (2003b). Not All Rivals Look Alike: Estimating an Equilibrium Model of the Release Date Timing Game. Working Paper, Stanford University.

Elberse, Anita (2002). Demand And Supply Dynamics For Sequentially Released Products In International Markets: An Empirical Application To Motion Pictures. PhD Dissertation, London Business School, October 2002.

Elberse, Anita (2004). Marvel Enterprises. Harvard Business School Case, N9-505-001.

Elberse, Anita and Bharat Anand (2005). The Effectiveness of Pre-Release Advertising for Motion Pictures. Working Paper, Harvard Business School. January 2005.

Elberse, Anita \& Eliashberg, Jehoshua (2003). Demand and Supply Dynamics for Sequentially Released Products in International Markets: The Case of Motion Pictures. Marketing Science 22 (3, Summer), 329-354.

Eliashberg, Jehoshua (2005). The Film Exhibition Business: Critical Issues, Practice and Research. In Charles C. Moul (Editor). A Concise Handbook of Movie Industry Economics. New York City, New York: Cambridge University Press, 138-162.

Eliashberg, Jehoshua, Jedid-Jah Jonker, Mohanbir S. Sawhney, and Berend Wierenga (2000). MOVIEMOD: An Implementable Decision-Support System for Prerelease Market Evaluation of Motion Pictures. Marketing Science, 19(3), 226-243.

Eliashberg, Jehoshua, Steven J. Miller, Sanjeev Swami, Charles B. Weinberg, and Berend Wierenga (2003) “Marketing Models for Movie Managers: Model Development and Implementation Experience”, Marketing Science Conference, University of Maryland, June.

Eliashberg, J., \& Sawhney, M. S. (1994). Modeling Goes to Hollywood: Predicting Individual Differences in Movie Enjoyment. Management Science, 40(9), 1151-1173.

Eliashberg, J., \& Shugan, S. M. (1997). Film critics: Influencers or predictors? Journal of Marketing, 61(April), 68-78.

Eliashberg, Jehoshua, Sanjeev Swami, Charles B. Weinberg, and Berend Wierenga (2001). Implementing and Evaluating SILVERSCREENER: A Marketing Management Support System for Movie Exhibitors. Interfaces, Vol. 31: No. 3, Part 2 of 2, May-June, pp. S108S127.

Eliashberg, Jehoshua, Sanjeev Swami, Charles B. Weinberg, and Berend Wierenga (2005). Operations Research in the Movies: Scheduling the Multiplexes. Working Paper, The Wharton School. 
Filson, Darren, David Switzer, and Portia Besocke (2005). At The Movies: The Economics Of Exhibition Contracts, Economic Inquiry, 43 (2), 354-369.

Frank, B. (1994). Optimal Timing of Movie Releases in Ancillary Markets: The Case of Video Releases. Journal of Cultural Economics, 18, 125-133.

Frank, R.H., \& Cook, P. J. (1995). The Winner-Take-All Society. New York: The Free Press. Gambaro, Marco (2004). “The Relationship Between Different Distribution Channels For Movies: Some Lessons From The Case Of Free Television”. 15 ${ }^{\text {th }}$ ITS Conference, September 2-4, Berlin.

Godes, David and Dina Mayzlin (2004). Using Online Conversations to Study Word of Mouth Communication. Marketing Science, 23 (4) 545-560.

Goettler, Ronald L. and Philip Leslie (2004). Co financing to Manage Risk in the Motion Picture Industry. Working Paper, August 2004.

Gruca, Thomas (2000). The IEM Movie Box Office Market Integrating Marketing and Finance using Electronic Markets. Journal of Marketing Education, 22: 5-14.

Hanssen, Andrew F. (2000). The Block-Booking of Films: A Re-Examination. Journal of Law and Economics, 43, October, pp. 395-426.

Hauser, John R (2001). Metrics Thermostat. Journal of Product Innovation Management, 18, 134153.

Hennig-Thurau, Thorsten, Gianfranco Walsh and Oliver Wruck (2001). An Investigation into the Factors Determining the Success of Service Innovations: The Case of Motion Pictures. Academy of Marketing Science Review, 6.

Hirschman, Elizabeth C., and Holbrook, Morris B. (1982). Hedonic Consumption: Emerging Concepts, Methods, and Propositions. Journal of Marketing, 46(Summer), 92-101.

Holbrook, M. B. (1999). Popular Appeal versus Expert Judgments of Motion Pictures. Journal of Consumer Research, 26 (September), 144-155.

Holbrook, Morris B. and Elizabeth C. Hirschman (1982). The Experiential Aspects of Consumption: Consumer Fantasies, Feelings and Fun. Journal of Consumer Research, 9(2), 132-140.

Holbrook, M. B., \& Schindler, R. M. (1996). Market Segmentation Based on Age and Attitude towards the Past: Concepts, Methods, and Findings Concerning Nostalgic Influences on Customer Tastes. Journal of Business Research, 37(1), 27-39.

Husted, Bryan W. (2000). The Impact of National Culture on Software Piracy. Journal of Business Ethics, 26, pp. 197-211

Jedidi, K., Krider, R. E., \& Weinberg, C. B. (1998). Clustering at the Movies. Marketing Letters, 
9(4), 393-405.

Jones, J. Morgan, \& Ritz, Christopher J. (1991). Incorporating Distribution into New Product

Diffusion Models. International Journal of Research in Marketing, 8(June), 91-112.

Jowett, G. S. (1985). Giving Them What They Want: Movie Audience Research Before 1950. B.

A. Austin (Editor), Current Research in Film: Audiences, Economics, and Law (Volume

1) (pp. 19-36). Norwood, NJ: Ablex.

Katz E. and P.F. Lazarsfeld (1955). Personal Influence. Illinois: Free Press.

Knapp, S., \& Sherman, B. L. (1986). Motion Picture Attendance: A Market Segmentation Approach. B. A. Austin (Editor), Current Research in Film: Audiences, Economics, and Law (Volume 2) (pp. 35-46). Norwood, NJ: Ablex.

Kotler, Philip, 1973-4, ‘Atmospherics as a Marketing Tool’, Journal of Retailing, 49: 48-63.

Krider, R. E., \& Weinberg, C. B. (1998). Competitive Dynamics and the Introduction of New Products: The Motion Picture Timing Game. Journal of Marketing Research, 35 (February), 1-15.

Lampel, J., \& Shamsie, J. (2000). Critical Push: Strategies for Creating Momentum in the Motion Picture Industry. Journal of Management, 26(2), 233-257.

Lassner, R. (1944). Sex and Age Determinants of Theatre and Movie Interests. Journal of General Psychology, 31, 241-271.

Lazersfeld, P. (1947). Audience Research in the Movie Field. Annals of the American Academy of Political and Social Sciences, 254(November), 160-168.

Leenders, Mark A.A.M. and Jehoshua Eliashberg (2004) “Antecedents and Consequences of Third-Party Products Evaluation Systems: Lessons from the International motion Picture Industry” Working Paper, The Wharton School.

Lehmann, Donald R., \& Weinberg, Charles B. (2000). Sales Through Sequential Distribution Channels: An Application to Movies and Videos. Journal of Marketing, 64(3) 18-33.

Levy, M and Barton A. Weitz 2001, Retailing Management, 4rth edition. McGraw-Hill IRWIN.

Lewis, Howard T. (1933). The Motion Picture Industry. New York: D. Van Nostrand.

Lewison, D.M. 1994, Retailing, 5th edition. New York: Macmillan Publishing Company.

Linton, J. M., \& Petrovich, J. A. (1988). The Application of the Consumer Information Acquisition Approach to Movie Selection: An Exploratory Study. B. A. Austin (Editor), Current Research in Film: Audiences, Economics, and Law (Volume 4) (pp. 24-44). Norwood, NJ: Ablex.

Little, John D.C. (1966). A Model of Adaptive Control of Promotional Spending. Operations Research, 14, 6, 1075-1098. 
Litman, B. R. (1983). Predicting Success of Theatrical Movies: An Empirical Study. Journal of Popular Culture, 16, 159-175.

Litman, B. R., \& Ahn, H. (1998). Predicting Financial Success of Motion Pictures. B. R. Litman The Motion Picture Mega-Industry. Needham Heights, MA: Allyn \& Bacon.

Litman, B. R., \& Kohl, L. S. (1989). Predicting Financial Success of Motion Pictures: The '80s Experience. Journal of Media Economics, 2, 35-50.

McQuail, D. (1994). Mass Communication Theory: An Introduction (3rd ed.). London: Sage.

Miller, D., \& Shamsie, J. (1996). The Resource Based View of the Firm in Two Environments: The Hollywood Film Studios From 1936 to 1965. Academy of Management Journal, 39, 519-543.

Miller, D., \& Shamsie, J. (2001). Learning Across the Life Cycle: Experimentation and Performance Among the Hollywood Studio Heads. Strategic Management Journal, 22, 725-745.

Miller, D. (1999). Strategic Responses to the Three Kinds of Uncertainty: Product Line Simplicity at the Hollywood Film Studios. Journal of Management, 25(1), 97.

Moller, K., \& Karppinen, P. (1983). Role of Motives and Attributes in Consumer Motion Picture Choice. Journal of Economic Psychology, November, 239-262.

Mortimer, Julie (2004). Vertical Contracts in the Video Rental Industry. Working Paper, Harvard University. April 2004.

Moul, C. C. (2004). Word-of-Mouth versus Market Saturation: Explaining Demand Dynamics for Movies and Music. Working Paper, Department of Economics, Washington University.

MPAA (2004). MPAA Economic Review. [www.mpaa.org].

Neelamegham, R., \& Chintagunta, P. (1999). A Bayesian Model to Forecast New Product Performance in Domestic and International Markets. Marketing Science, 18(2), 115-136.

Neelamegham, R., \& Jain, D. (1999). Consumer Choice Process for Experience Goods: An Econometric Model and Analysis. Journal of Marketing Research, 36(3), 373-386.

Nelson, R. A., Donihue, M. R., Waldman, D. M., \& Wheaton, C. (2001). What's an Oscar Worth? Economic Inquiry, 39(1), 1-16.

Norton, John A. and Frank M. Bass (1987). A Diffusion Theory of Adoption and Substitution for Successive Generations of High-Technology Products. Management Science 33(9), 10691086.

O'Brien, J. M. (1977). Experiencing the Popular Film: An Audience Gratifications Study. Unpublished PhD Dissertation: Northwestern University.

Oberholzer, Felix and Koleman Strumpf (2004). The Effect of File Sharing On Record Sales: An 
Empirical Analysis. Working Paper, March 2004.

Orbach, Barak Y. (2004). Antitrust and Pricing in the Motion Picture Industry. Yale Journal on Regulation 21(2), 317-367.

Orbach, Barak Y. and Liran Einav (2001) “Uniform Prices for Differentiated Goods: The Case of the Movie-Theater Industry” Working Paper, Harvard Olin Discussion Paper No. 337, October.

Palmgreen, P., Cook, P. L., Harvill, J. G., \& Helm, D. M. (1988). The Motivational Framework of Moviegoing: Uses and Avoidances of Theatrical Films. B. A. Austin (Editor), Current Research in Film: Audiences, Economics, and Law (Volume 4) (pp. 1-23). Norwood, NJ: Ablex.

Palmgreen, P., \& Lawrence, P. A. (1991). Avoidances, Gratifications, and Consumption of Theatrical Films: The Rest of the Story. B. A. Austin (Editor), Current Research in Film: Audiences, Economics, and Law (Volume 5) (pp. 39-55). Norwood, NJ: Ablex.

Peitz, Martin and Patrick Waelbroeck (2003). Piracy of Digital Products: A Critical Review of the Economics Literature. CESifo Working Paper Series No. 1071, November 2003.

Peitz, Martin and Patrick Waelbroeck (2004). The Effect of Internet Piracy on CD Sales: CrossSection Evidence. Working Paper No. 1122, January, CESifo Working Papers Series.

Prag, J., \& Casavant, J. (1994). An Empirical Study of the Determinants of Revenues and Marketing Expenditures in the Motion Picture Industry. Journal of Cultural Economics, 18, 217-235.

Quelch, John, Anita Elberse and Anna Harrington (2004). The Passion of the Christ (A). Harvard Business School Case, 9-505-020.

Radas, S., \& Shugan, S. M. (1998). Seasonal Marketing and Timing New Product Introductions. Journal of Marketing Research, 35(3), 296-315.

Rangaswamy, Arvind, Jehoshua Eliashberg, Raymond R. Burke, and Jerry Wind (1989). Developing Marketing Expert Systems: An Application to International Negotiations. Journal of Marketing, 53(4), 24-49.

Ravid, S. A. (1999). Information, Blockbusters, and Stars: A Study of the Film Industry. Journal of Business, 72(4), 463-492.

Raut, S., S. Swami, E. Lee, and C.B. Weinberg (2004), Contract Design in Complex Supply Chains Using Genetic Algorithm and Game Theoretic Approaches. Proceedings of the $9^{\text {th }}$ International Symposium on Logistics, July, IIM, Bangalore.

Sawhney, Mohanbir S., \& Jehoshua Eliashberg (1996). A Parsimonious Model for Forecasting Gross Box-Office Revenues of Motion Pictures. Marketing Science, 15(2), 113-131. 
Schmitt, Brend H. (1999). Experiential Marketing. New York City, New York: The Free Press. Scott, Allen J. On Hollywood: The Place, The Industry. Princeton University Press.

Screen Digest (2002). Report on the Implications of Digital Technology for the Film Industry. UK, Department for Culture, Media and Sport, Creative Industries Division. September 2002.

Shapiro, M. E., \& Biggers, T. (1987). Emotion-Eliciting Qualities in the Motion Picture Viewing Situation and Audience Evaluations. B. A. Austin (Editor), Current Research in Film: Audiences, Economics, and Law (Volume 3) (Vol. 3pp. 1-11). Norwood, NJ: Ablex.

Showbiz Data (2004). Production. [www.showbizdata.com]. Accessed January 2004.

Shugan, Steven M. \& Joffre Swait (2000). Enabling Movie Design and Cumulative Box Office Predictions. ARF Conference Proceedings.

Shugan, Steven M. (2000a). Forecasting the Box Office Of New Films Before They Are Made. Working Paper, University of Florida.

Shugan, Steven M. (2000b). Recent Research on the Motion Picture Industry. Proceedings of the Inaugural Business and Economics Scholars Workshop in Motion Picture Industry Studies. Eliashberg and Mallen (Editors). October 2000, page 65-86.

Shugan, Steven M. (2004). Editorial: Endogeneity in Marketing Decisions Models. Marketing Science, 23(1), 1-3.

Simonoff, J. S., \& Sparrow, I. R. (2000). Predicting Movie Grosses: Winners and Losers, Blockbusters and Sleepers. Chance, 13(3), 15-24.

Smith, S. P., \& Smith, V. K. (1986). Successful Movies: A Preliminary Empirical Analysis. Applied Economics, 18, 501-507.

Sochay, S. (1994). Predicting the Performance of Motion Pictures. Journal of Media Economics, 7(4), 1-20.

Sood, Sanjay and Xavier Dreze (2004). Brand Extensions of Hedonic Goods: Movie Sequel Evaluations. Working Paper.

Sorenson, Olav and David Waguespack (2003). Social Networks and Exchange: Self-Confirming Dynamics in Hollywood. Working Paper, November, 2003.

Spann, Martin \& Bernd Skiera (2003). Internet-Based Virtual Stock Markets for Business Forecasting. Management Science, 49 (10), 1310-1326.

Squire, Jason E. (2004). The Movie Business Book (Third Edition). Fireside.

Standard \& Poor's (2004). Industry Surveys: Movies \& Home Entertainment. February 12, 2004.

Swami, Sanjeev, Jehoshua Eliashberg, and Charles B. Weinberg (1999). SilverScreener: A Modeling Approach to Movie Screens Management. Marketing Science, 18(3), 352-372. 
Swami, S., Puterman, M. L., \& Weinberg, C. B. (2001). Play It Again Sam? Optimal Replacement Policies for Motion Picture Exhibitor. Manufacturing \& Service Operations Management, 3(4), 369-386.

The Economist (2003). Big Trouble for Big Pharma. December 6, 2003, p. 55.

The New York Times (2000). Now on the PC Screen: Scent of a Kitchen, September 13, 2000.

The Hollywood Reporter (1998). Bronfman: Event Films Need Event Ticket Prices. April 1, 1998.

The Hollywood Reporter (2004). If You Spend It They Will Come. May 18, 2004, S-3.

The Los Angeles Times (2002). Showtime for Theater Owners; More Americans went to movies this year than anytime since 1959. December 26, 2002, p. C1.

The Philadelphia Inquirer (2003). TV Ads Play On The Big Screen. February 2, 2003, p. B1.

The Wall Street Journal (2003). Handicapping 'Seabiscuit'. July 28, 2003.

The Wall Street Journal (2004a). Merger Could Alter Hollywood Balance of Power. February 13, 2004, B1.

The Wall Street Journal (2004b). Summer Movies-look Who’s Starring Now. April 16, 2004, W1.

The Wall Street Journal (2004c). Summer Film Fight. April 26, 2004. B1.

The Wall Street Journal (2004d). Boss Talk: Q-and-A with NBC Universal's Bob Wright.

December 22, 2004.

The Wall Street Journal (2005). Themed Megaplexes Entice Shoppers to Malls. June 16, 2005.

Tyagi, R.K. 2004. Technological Advances, Transaction Costs and Consumer Welfare. Marketing Science, 23 (3) 335-344.

Urban, Glen L. \& John R. Hauser (1980). Design and marketing of new products. Prentice-Hall, Englewood Cliff, NJ.

UK Film Council (2002). The Indian Media and Entertainment Industry. Report by Parminder Vir, John Woodward \& Neil Watson, April 2002. Accessed January 2003. [http://www.ukfilmcouncil.org.uk/filmindustry/india/].

U.S. Department of Labor (2004). 2001 National Industry-Specific Occupational Employment and Wage Estimates: SIC 78 - Motion Pictures. Web site, accessed May 2004, http://www.bls.gov/oes/2001/oesi2_78.htm.

Variety (2002). Is H'wood's Biz Model outdated? December 10, 2002.

Variety (2003a). Bring Your Own Money. April 27, 2003.

Variety (2003b). Rough Cuts On Movie Money. April 27, 2003.

Variety (2003c). How Great Is Day-And-Date? May 11, 2003. 
Variety (2003d). How'd: A Sequel Opportunity Town. June 15, 2003.

Variety (2003e). Falling off the Brand Wagon: Studios Cope with Ad-versity in Lining Up Promo

Partners. October 20, 2003.

Variety (2004a). The Incredible Shrinking Aud. January 4, 2004.

Variety (2004b). Movie Sequels Click With Consumers. January 11, 2004.

Variety (2004c). Net Heads Finally Get Some Respect. April 18, 2004.

Vogel, Harold L. (2001). Entertainment Industry Economics. Cambridge University Press, Cambridge: New York.

Wagner, S.C., and M.C. Gilly (2001). Considerations in Ethical Decision-Making and Software Piracy. Journal of Business Ethics, 29, pp. 161-167.

Wallace, W. T., Seigerman, A., \& Holbrook, M. B. (1993). The Role of Actors and Actresses in the Success of Films: How Much is a Movie Star Worth? Journal of Cultural Economics, 17(1), 1-27.

Walls, W. D. (1998). Product Survival at the Cinema: Evidence from Hong Kong. Applied Economics Letters, 5, 215-219.

Walls, W. D. (1999). Measuring and Managing Uncertainty with an Application to the Hong Kong Movie Business. Working Paper, School of Economics and Finance, University of Hong Kong.

Weinberg, Charles B. (2005). Profits Out of the Picture: Research Issues and Revenue Sources Beyond The North American Box Office. In Charles C. Moul (Editor). A Concise Handbook of Movie Industry Economics. New York City, New York: Cambridge University Press, 163-203.

Weinstein, Mark (1998). Profit-Sharing Contracts In Hollywood: Evolution And Analysis. Journal of Legal Studies, January, pp.67-112.

Williams, W. Jr., \& Shapiro, M. E. (1985). A Study of the Effects In-Home Entertainment Alternatives Have on Film Attendance. B. A. Austin (Editor), Current Research in Film: Audiences, Economics, and Law (Volume 1) (pp. 93-100). Norwood, NJ: Ablex.

Wind, J. \& V. Mahajan (1997). Issues and Opportunities In New Product Development; An Introduction to the Special Issue. Journal of Marketing Research, 34 (February), 1-12.

Wolf, Michael J. (1999). The Entertainment Economy, New York City, New York: Times Books.

Wyatt, R. O., \& Badger, D. P. (1984). How Reviews Affect Interest in and Evaluation of Films. Journalism Quarterly, 61, 874-878.

Zuckerman, Ezra W. and Tai Young Kim (2003), The Critical Trade-off: Identity Assignment and 
Box Office Success in the Feature Film Industry. Industrial and Corporate Change, 12, 1, 27-67.

Zufryden, F. S. (1996). Linking Advertising to Box Office Performance of New Film Releases: A Marketing Planning Model. Journal of Advertising Research, July-August, 29-41.

Zufryden, F. S. (2000). New Film Website Promotion and Box-Office Performance. Journal of Advertising Research, (January-April), 55-64. 